University of Nebraska - Lincoln

DigitalCommons@University of Nebraska - Lincoln

\title{
Paleoclimatic Significance of Chemical Weathering in Loess- Derived Paleosols of Subarctic Central Alaska
}

Daniel R. Muhs

U.S. Geological Survey, dmuhs@usgs.gov

Thomas A. Ager

U.S. Geological Survey, tager@usgs.gov

Gary Skipp

U.S. Geological Survey, gskipp@usgs.gov

Jossh Beann

U.S. Geological Survey

James Budahn

U.S. Geological Survey

See next page for additional authors

Follow this and additional works at: https://digitalcommons.unl.edu/usgsstaffpub

Part of the Earth Sciences Commons

Muhs, Daniel R.; Ager, Thomas A.; Skipp, Gary; Beann, Jossh; Budahn, James; and McGeehin, John P., "Paleoclimatic Significance of Chemical Weathering in Loess-Derived Paleosols of Subarctic Central Alaska" (2008). USGS Staff -- Published Research. 151.

https://digitalcommons.unl.edu/usgsstaffpub/151

This Article is brought to you for free and open access by the US Geological Survey at DigitalCommons@University of Nebraska - Lincoln. It has been accepted for inclusion in USGS Staff -- Published Research by an authorized administrator of DigitalCommons@University of Nebraska - Lincoln. 


\section{Authors}

Daniel R. Muhs, Thomas A. Ager, Gary Skipp, Jossh Beann, James Budahn, and John P. McGeehin 


\section{Paleoclimatic Significance of Chemical Weathering in Loess-Derived Paleosols of Subarctic Central Alaska}

\author{
Daniel R. Muhs*§ \\ Thomas A. Ager* \\ Gary Skipp* \\ Jossh Beann* \\ James Budahn† and \\ John P. McGeehint \\ *U.S. Geological Survey, MS 980, Box \\ 25046, Federal Center, Denver, \\ Colorado 80225, U.S.A. \\ $\dagger$ †.S. Geological Survey, MS 974, Box \\ 25046, Federal Center, Denver, \\ Colorado 80225, U.S.A. \\ \#U.S. Geological Survey, MS 926A, \\ National Center, Reston, Virginia \\ 20192, U.S.A. \\ $\S$ Corresponding author: \\ dmuhs@usgs.gov
}

\begin{abstract}
Chemical weathering in soils has not been studied extensively in high-latitude regions. Loess sequences with modern soils and paleosols are present in much of subarctic Alaska, and allow an assessment of present and past chemical weathering. Five sections were studied in detail in the Fairbanks, Alaska, area. Paleosols likely date to mid-Pleistocene interglacials, the last interglacial, and early-to-midWisconsin interstadials. Ratios of mobile ( $\mathrm{Na}, \mathrm{Ca}, \mathrm{Mg}, \mathrm{Si}$ ) to immobile ( $\mathrm{Ti}$ or $\mathrm{Zr}$ ) elements indicate that modern soils and most interstadial and interglacial paleosols are characterized by significant chemical weathering. $\mathrm{Na}_{2} \mathrm{O} / \mathrm{TiO}_{2}$ is lower in modern soils and most paleosols compared to parent loess, indicating depletion of plagioclase. In the clay fraction, smectite is present in Tanana and Yukon River source sediments, but is absent or poorly expressed in modern soils and paleosols, indicating depletion of this mineral also. Loss of both plagioclase and smectite is well expressed in soils and paleosols as lower $\mathrm{SiO}_{2} / \mathrm{TiO}_{2}$. Carbonates are present in the river source sediments, but based on $\mathrm{CaO} / \mathrm{TiO}_{2}$, they are depleted in soils and most paleosols (with one exception in the early-to-mid-Wisconsin period). Thus, most soilforming intervals during past interglacial and interstadial periods in Alaska had climatic regimes that were at least as favorable to mineral weathering as today, and suggest boreal forest or acidic tundra vegetation.
\end{abstract}

\section{Introduction}

Paleosols have the potential for yielding considerable paleoclimatic information. Numerous studies, using degree of development of paleosols, have made paleoclimatic interpretations in North America, Asia, Europe, and elsewhere (see review in Birkeland, 1999). Paleoclimatic interpretations are often made by comparing paleosols with modern soils in the same region. Many paleoclimatic inferences, particularly those related to precipitation, are made on the basis of degree of chemical weathering in paleosols, because this process requires water.

Loess is widely distributed in Alaska and is geographically the most extensive surficial deposit in the region (Fig. 1). In central Alaska, studies by Westgate et al. (1990) indicate that the Alaskan loess record may extend back to $\sim 3.0 \mathrm{Ma}$. Paleosols are common in central Alaskan loess, but there are, nevertheless, few data on what significance such features may have for interpreting paleoclimate. It is generally agreed that the presence of paleosols represents the slowing of loess deposition, such that pedogenesis can keep ahead of sedimentation (Begét, 1996, 2001; Muhs et al., 2003a; Muhs and Bettis, 2003). However, there are uncertainties as to what degree of chemical weathering may have occurred during past periods of soil formation and therefore what paleoclimate may have prevailed in central Alaska at the time.

On first principles, it could be argued that one might not expect much chemical weathering in soils found in the subarctic climate of central Alaska. Indeed, Anderson (2007), in a recent review, points out that temperature is a major limiting factor in chemical weathering in cold climates, such as those areas close to active glaciers. Mean annual temperature in Fairbanks is $-3.0{ }^{\circ} \mathrm{C}$ for the period 1971-2000 (http://climate.gi.alaska.edu/Climate/Location/ Interior/Fairbanks.html). Much of the year, temperatures are well below freezing. This means that liquid water, a prerequisite for significant mineral alteration by chemical processes, is not available for long periods. Precipitation in the region is low $(\sim 200-300 \mathrm{~mm}$ $\mathrm{yr}^{-1}$ ), and potential evapotranspiration (as calculated strictly from temperature and day length) exceeds precipitation. Nevertheless, a positive moisture balance is a prerequisite for significant chemical weathering. As pointed out by Guthrie (1990), however, this potential negative water balance is often countered in central Alaska by minimal downward percolation, due to shallow permafrost, and minimal evaporation, due to forest cover, a relatively long-lasting snow cover, and a thick soil $\mathrm{O}$ horizon cover. Nevertheless, shallow permafrost in many parts of central Alaska may also inhibit chemical weathering in all but the uppermost soil horizons that constitute the active layer. Finally, the rate of organic matter decomposition is low, thus minimizing the release of organic acids that could aid in mineral alteration.

Other factors in subarctic Alaska favor chemical weathering. Anderson (2007) presents a major review of the relations between chemical weathering and glacial landscapes. She points out that although temperature is a limiting factor for chemical weathering in areas immediately adjacent to active glaciers, distal zones, characterized by outwash and loess, generally have higher temperatures and are therefore more favorable for chemical weathering. Furthermore, loess is largely a product of glacial grinding in Alaska. Anderson (2007) emphasizes that glacial grinding produces very fine particle sizes and that this process can be thought of as a generator of mineral surface area. Loess, as a 


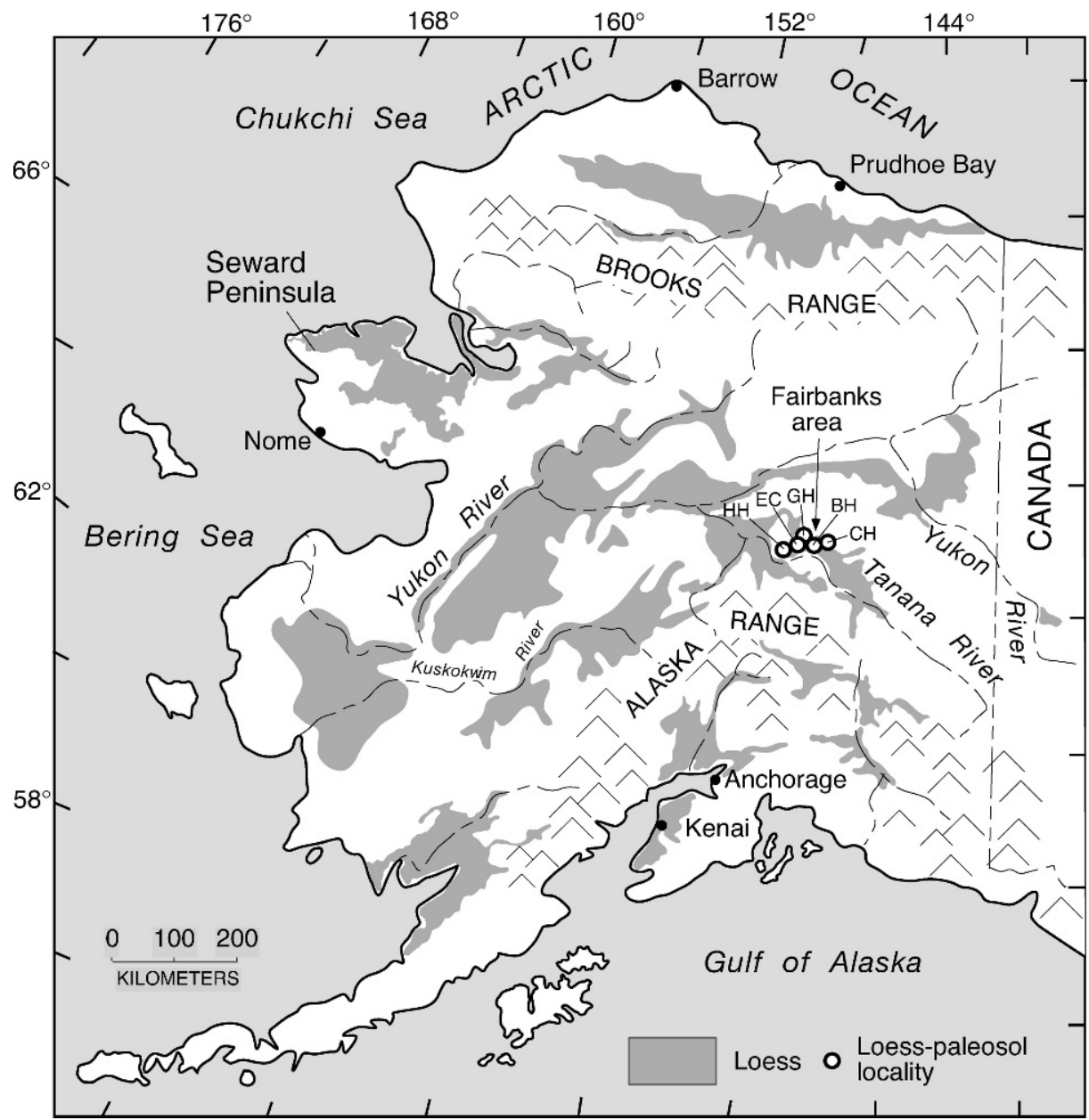

FIGURE 1. Map showing the distribution of loess in Alaska (adapted from Hopkins, 1963, for the Seward Peninsula and Péwé, 1975 , for the rest of the state) and localities studied. Abbreviations: HH, Halfway House; EC, Eva Creek; CH, Chena Hot Springs Road; BH, Birch Hill; GH, Gold Hill. glaciogenic sediment, has a greater surface area than its source rocks and is thus much more reactive chemically.

Several recent studies illustrate the uncertainties about the nature and degree of chemical weathering in loess-derived paleosols of Alaska and adjacent Yukon Territory. For example, at the Gold Hill loess section (Fig. 2) near Fairbanks (Begét, 1990; Preece et al., 1999; Muhs et al., 2003a), Vlag et al. (1999) studied loess and paleosols. They reported that mobile elements such as $\mathrm{Ca}, \mathrm{Mg}, \mathrm{Na}$, and $\mathrm{K}$ show only minor variations as a function of depth in the loess-paleosol sequence and interpreted these data to indicate that leaching has not been a significant process. In contrast, Liu et al. (1999), studying the properties of magnetic minerals at the Halfway House loess section (Fig. 2), west of Fairbanks (Begét et al., 1990; Preece et al., 1999; Muhs et al., 2003a), reported that alteration of magnetic minerals in paleosols has been significant. However, Liu et al. (1999) suggested that waterlogging, rather than leaching under well-drained conditions, has been the predominant environmental control on soil formation. Begét (2001) reported that there are chemical weathering pits on the surfaces of Fe-Ti oxide minerals and feldspars, suggesting significant chemical weathering in loessderived soils. In contrast, Lagroix and Banerjee (2002) felt that rates of pedogenesis overall were minimal in Alaskan loess sequences. Höfle and Ping (1996) reported little or no chemical weathering in last-glacial, loess-derived paleosols on the Seward Peninsula of Alaska, as did Sanborn et al. (2006) for paleosols of similar age in Yukon Territory. Guthrie (1990, 2001, p. 553) stated that Pleistocene soils in Alaska were more basic (alkaline) than modern boreal forest and tundra soils, and therefore formed under a grassland cover, in a more arid climate. Although not stated explicitly, it is likely that Guthrie $(1990,2001)$ was referring here to soils that may have formed during the last glacial period, rather than during past interglacials or interstadials.

Too few data exist to ascertain whether central Alaskan, loess-derived paleosols have experienced significant alterations of primary minerals and under what climatic and vegetation conditions. The purpose of the present study is to help fill this gap. Five loess sections in the Fairbanks area (Figs. 1, 2) were studied in detail by Muhs et al. (2001a, 2003a). These studies reported loess stratigraphy, criteria for the recognition of paleosols, tephra chronological information, and radiocarbon and ${ }^{10} \mathrm{Be}$ age estimates of loess and paleosols. In this paper, we present major element geochemistry and mineralogy of these loess sections and assess the degree of chemical weathering.

\section{Methods}

Mineralogy of selected loesses from all five sections was determined on pulverized bulk samples using X-ray diffraction (XRD) methods (Moore and Reynolds, 1989). In addition, mineralogy of two complete sections, Gold Hill and Halfway House, was determined by bulk XRD using a slow scanning speed in order to assess relative abundances of quartz, K-feldspar, and plagioclase more effectively. Clay mineralogy was determined by XRD on oriented samples after four treatments: air-dry, ethylene glycol-solvated, air-dry-K-saturated, and heat treatment $\left(550{ }^{\circ} \mathrm{C}\right.$ for one hour).

Previous studies (Birkeland, 1999; Muhs et al., 2001b) have shown that ratios of mobile elements $(\mathrm{Na}, \mathrm{K}, \mathrm{Ca}, \mathrm{Mg}, \mathrm{Si})$ to 


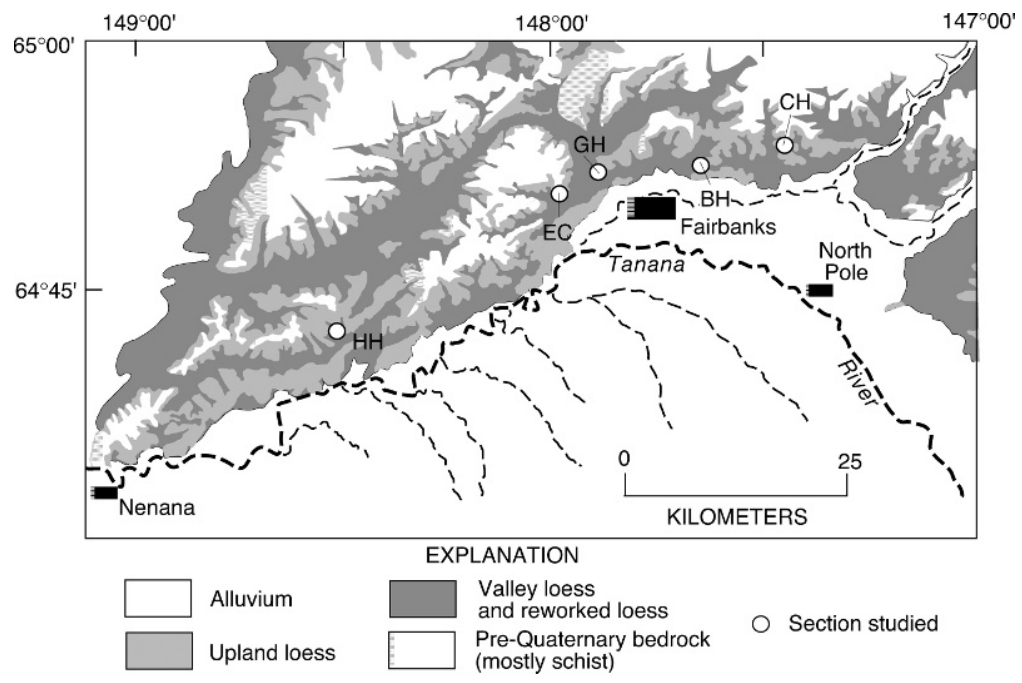

FIGURE 2. Map showing the surficial geology of the Fairbanks area and locations of sites where stratigraphic studies were conducted. Geology from Péwé et al. (1966). HH, Halfway House; EC, Eva Creek; GH, Gold Hill; BH, Birch Hill; CH, Chena Hot Springs Road.

immobile elements $(\mathrm{Ti}, \mathrm{Zr}$ ) provide useful proxies for the degree of chemical weathering of detrital loess minerals. Major element concentrations of unaltered loess and paleosols were determined by wavelength-dispersive X-ray fluorescence on pulverized samples. Zirconium concentrations were determined by either energydispersive or wavelength-dispersive $\mathrm{X}$-ray fluorescence, except for river silts. For river silts, both $\mathrm{Ca}$ and $\mathrm{Zr}$ abundances were determined by instrumental neutron activation analysis (Budahn and Wandless, 2002). These data are reported in Muhs and Budahn (2006), but are used here to compare with loess and paleosol data. Estimates of calcium carbonate content were made following gas evolution after dissolution with $\mathrm{HCl}$.

We present six new radiocarbon ages from two of the sections studied (Table 1). At Eva Creek (Fig. 3), plant macrofossils that appear to be grass or sedge-derived rosettes were analyzed. Deeper in the same section, humic acids were extracted from two paleosols for radiocarbon analyses. Extraction methods for the samples from Eva Creek follow Abbott and Stafford (1996). At Halfway House (Fig. 4), we found charcoal in the three uppermost paleosols. Muhs et al. (2003a) previously reported humic-acid radiocarbon ages from these paleosols, but new accelerator mass spectrometric (AMS) radiocarbon ages of the charcoal samples are reported here. The cleaning, extraction, and graphitization methods for charcoal at Halfway House follow those outlined in McGeehin et al. (2001). For all samples, concentrations of ${ }^{14} \mathrm{C}$ were measured by accelerator mass spectrometry at the Center for Accelerator Mass Spectrometry (CAMS), Lawrence Livermore National Laboratory. Approximate calibrated ("calendar year") age estimates are given for radiocarbon ages in the figures and text, calculated from conversion data given in Fairbanks et al. (2005).

\section{Landscape Position, Stratigraphy, Ages, and Correlation}

The Halfway House, Birch Hill, and Chena Hot Springs Road sections are all found in what Péwé et al. (1966) mapped as upland loess (Fig. 2). We agree with this mapping and interpret the sediments in these sections to be composed largely of direct, air-fall-derived loess. The Gold Hill and Eva Creek sections are situated within what is probably a transitional facies between upland loess and what Péwé et al. (1966) mapped as valley-bottom silts, composed of both direct, air-fall loess and reworked loess (Fig. 2). Thus, some of the sediments in the latter two sections could be loess that has been reworked from adjacent hillslopes.

Details of most of the loess stratigraphy and paleosol characteristics for the five sections studied are given in Muhs et al. (2001a, 2003a), but are summarized here. What are interpreted to be buried soils in Fairbanks-area loess can be identified on the basis of soil morphology, particularly soil colors. Unaltered loess in central Alaska typically has light brownish gray (2.5Y 6/2), light yellowish brown (2.5Y 6/3), or grayish brown (2.5Y 5/2) colors. Soil O or A horizons generally have $10 \mathrm{YR}$ or $7.5 \mathrm{YR}$ hues and almost always have much lower values and chromas that distinguish them from unaltered loess. Soil B horizons, where they occur, also have 10YR or 7.5YR hues with chromas that are much higher than unaltered loess. Organic matter contents are generally higher in paleosols. In all but the lowermost (and therefore oldest) parts of the Gold Hill and Birch Hill sections, units identified as paleosols have higher organic matter contents relative to superjacent and subjacent loess (Muhs et al., 2003a).

It is important to note that most paleosols in Fairbanks-area loess do not retain clear, horizontal boundaries between soil horizons. Cryoturbation processes, such as solifluction and frost

TABLE 1

Accelerator mass spectrometric (AMS) radiocarbon ages of humic acid extractions, charcoal and macrofossils from central Alaskan loess.

\begin{tabular}{|c|c|c|c|c|c|c|c|}
\hline Locality & Field \# & $\begin{array}{c}\text { Depth in } \\
\text { section }(\mathrm{m})\end{array}$ & $\begin{array}{c}\text { Laboratory \# } \\
\text { (see below) }\end{array}$ & CAMS \# & Material & $\begin{array}{l}\text { Radiocarbon } \\
\text { age (yr) }\end{array}$ & $\begin{array}{l}\text { Calendar } \\
\text { age (yr) }\end{array}$ \\
\hline \multirow{3}{*}{$\begin{array}{l}\text { Eva Creek, } \\
\text { lower section }\end{array}$} & AK-414 & 3.1 & NSRL-2820 & CAMS-24360 & Grass rosettes & $20,850 \pm 100$ & $\sim 25,000$ \\
\hline & AK-418 & 9.9 & NSRL-2821 & CAMS-24361 & Humic acids & $35,190 \pm 530$ & $\sim 41,000$ \\
\hline & AK-419 & 10 & NSRL-2822 & CAMS-24362 & Humic acids & $35,420 \pm 550$ & $\sim 41,000$ \\
\hline \multirow[t]{3}{*}{ Halfway House } & AK-226 & 3.98 & WW-5445 & CAMS-119521 & Charcoal & $>50,300$ & \\
\hline & AK-228 & 4.33 & WW-5446 & CAMS-119522 & Charcoal & $47,200 \pm 1500$ & \\
\hline & AK-240 & 6.26 & WW-5447 & CAMS-119523 & Charcoal & $>49,900$ & \\
\hline
\end{tabular}

Note: NSRL indicates University of Colorado laboratory number; WW indicates U.S. Geological Survey laboratory number. 


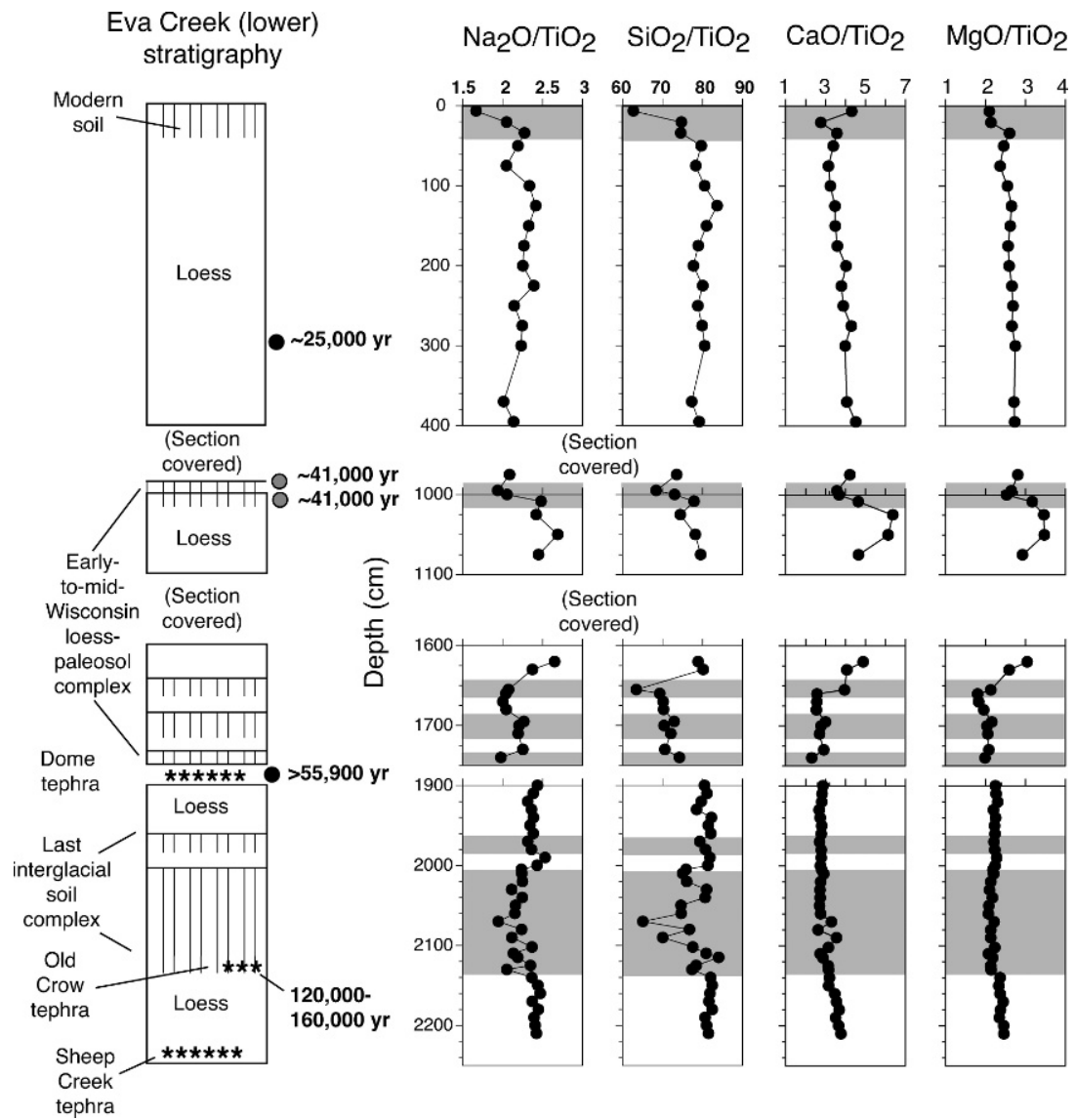

FIGURE 3. Loess stratigraphy, radiocarbon ages, and possible correlations at the Eva Creek (lower) section. Stratigraphy of the section from 1900 to $2200 \mathrm{~cm}$ is generalized from Muhs et al. (2001a). Gray shades mark paleosols. Fission-track age estimate for the Old Crow tephra is from Westgate et al. (1990). Black-filled circles are approximate calibrated radiocarbon ages of charcoal or macrofossils; gray-filled circles are approximate calibrated radiocarbon ages of humic acid extractions from paleosols (see text for discussion). Also shown are plots of $\mathrm{Na}_{2} \mathrm{O} / \mathrm{TiO}_{2}$, and $\mathrm{SiO}_{2} / \mathrm{TiO}_{2}$, $\mathrm{CaO} / \mathrm{TiO}_{2}$, and $\mathrm{MgO} / \mathrm{TiO}_{2}$ in the section.

heaving, have disturbed and mixed most soil horizons, sometimes to the extent of $\mathrm{B}$ horizons being overturned to the top of previously superjacent A horizons. In addition, parts of overlying and underlying loesses are often mixed into soils. Thus, on depth functions presented here, chemical properties reflective of pedogenesis sometimes are apparent in what is identified as "unaltered" loess immediately above or below what is identified as a paleosol.

\section{EVA CREEK}

Eva Creek is a small, first-order stream west of Fairbanks (Figs. 2, 3). Here, and on all figures related to it, we refer to this section as "Eva Creek (lower)" or simply "Eva Creek," to distinguish it from another section, farther up-valley, studied by McGeehin et al. (2001). Eva Creek (lower) has been studied by Péwé et al. (1997), Preece et al. (1999), and Muhs et al. (2001a).
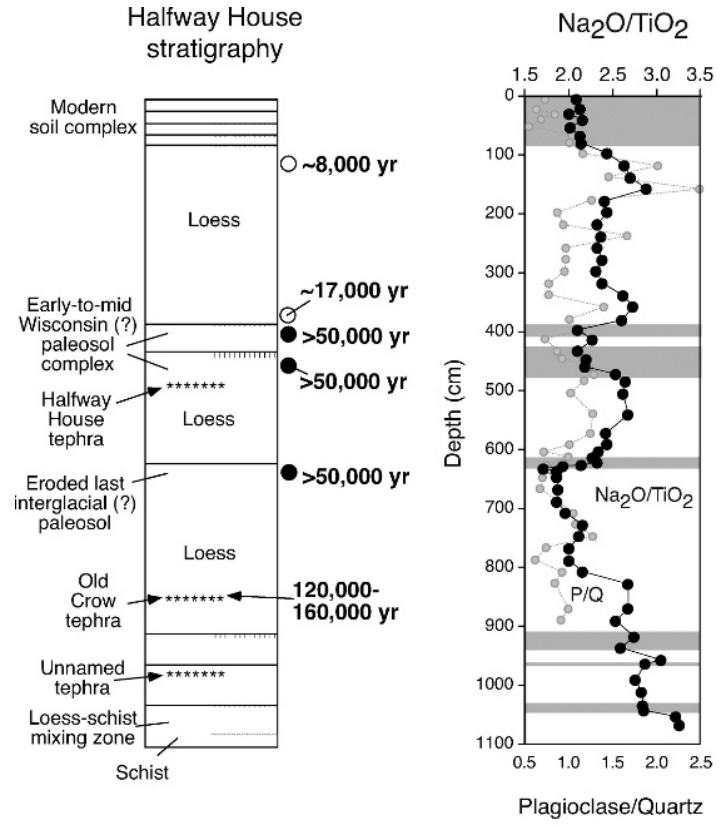
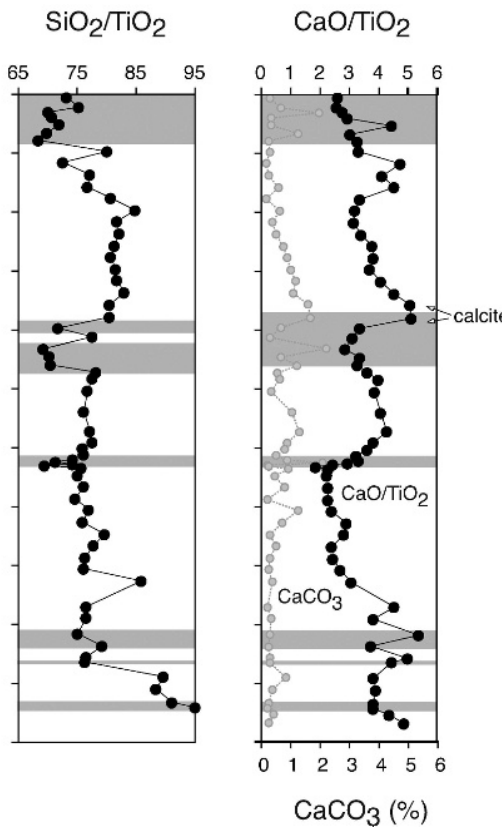

FIGURE 4. Loess stratigraphy, radiocarbon ages, selected ${ }^{10} \mathrm{Be}$ age estimates, and possible correlations (Muhs et al., 2003a) at the Halfway House section; fissiontrack age estimate for the Old Crow tephra is from Westgate et al. (1990). Open circles are ${ }^{10} \mathrm{Be}$ age estimates; black-filled circles are new radiocarbon ages of charcoal (see text for discussion). Also shown are plots of $\mathrm{Na}_{2} \mathrm{O} / \mathrm{TiO}_{2}$, plagioclase/quartz, $\quad \mathrm{SiO}_{2} / \mathrm{TiO}_{2}$, $\mathrm{CaO} / \mathrm{TiO}_{2}$, and $\mathrm{CaCO}_{3}$ in the section. Gray shades mark paleosols. 
The lower part of the section, at $\sim 2200-2300 \mathrm{~m}$ depth, is gray loess that contains the Sheep Creek tephra. Based on thermoluminescence (TL) ages of bracketing loess, the Sheep Creek tephra was estimated to be about $210,000-170,000 \mathrm{yr}$ old, although there are some stratigraphic inconsistencies with TL ages at one locality where it was studied (Berger et al., 1996) and the calculated age is beyond the TL age limit that is accepted by most luminescence geochronologists. The Old Crow tephra is found above the Sheep Creek tephra, and was dated by fission-track and TL methods to about 160,000-120,000 yr B.P. (Westgate et al., 1990; Berger and Péwé, 2001; Berger, 2003). Based on the stratigraphy at Eva Creek (lower) given in Muhs et al. (2001a), the Old Crow tephra is not continuous, but occurs in what is interpreted to be an ice-wedge cast that probably predates the last interglacial period and within cryoturbated parts of what is interpreted to be a last-interglacial paleosol complex. The last interglacial paleosol complex is found stratigraphically just below the Dome tephra (Muhs et al., 2001a). At another section, Chena Hot Springs Road, charcoal found in close association with the Dome tephra gave a radiocarbon age of $>55,900 \mathrm{yr}$ (Muhs et al., 2003a). Above the Dome tephra at Eva Creek there is a complex of at least three paleosols developed in loess or reworked loess up to a depth of $\sim 1600 \mathrm{~cm}$. At the time of our studies, the section was covered above this zone to a depth of $\sim 1100 \mathrm{~cm}$. Slightly more than $100 \mathrm{~cm}$ of section is exposed to just above $\sim 1000 \mathrm{~cm}$; humic acids from a paleosol at two depths in the upper part of this segment of section gave calibrated radiocarbon ages of $\sim 41,000 \mathrm{yr}$ (Table 1). The section is again covered above $\sim 900 \mathrm{~cm}$ depth, but is exposed in the upper $400 \mathrm{~cm}$. The modern soil is developed in the top part of the upper $400 \mathrm{~cm}$ of loess. What we interpret to be rosettes from either grass or sedge were found at a depth of $310 \mathrm{~cm}$ and gave a calibrated radiocarbon age of $\sim 25,000$ yr (Table 1).

\section{HALFWAY HOUSE}

The Halfway House section is not as thick as Eva Creek and the oldest loesses and paleosols, between $\sim 900$ and $\sim 1100 \mathrm{~cm}$ depth, are thin and undated (Fig. 4). The Old Crow tephra is found between $\sim 800$ and $900 \mathrm{~cm}$ depth. Above the Old Crow tephra, between $\sim 600$ and $\sim 650 \mathrm{~cm}$ depth, there is a wellexpressed, but thin paleosol that may date to some part of the last interglacial complex. We report here a new AMS radiocarbon age for charcoal from this paleosol that is $>49,900{ }^{14} \mathrm{C}$ yr B.P. (Table 1). At $\sim 500 \mathrm{~cm}$ depth, the loess overlying this paleosol contains the Halfway House tephra, which is undated. Above this tephra are two paleosols, at $\sim 400 \mathrm{~cm}$ depth. Muhs et al. (2003a) reported humic acid radiocarbon ages for these paleosols, interpreted as minimum ages. We report here two new AMS radiocarbon ages of charcoal from these soils that are significantly older. Charcoal in the lower of the two paleosols has an apparently finite age of 47,200 $\pm 1500{ }^{14} \mathrm{C}$ yr B.P. (Table 1). However, we interpret this as a minimum age because it is near the limit of the method. Furthermore, charcoal from the paleosol above it gave an age of $>50,300{ }^{14} \mathrm{C}$ yr B.P. Hence, on stratigraphic and radiocarbon grounds, we regard all three paleosols, the one between $\sim 600$ and $650 \mathrm{~cm}$, and the two at $\sim 400 \mathrm{~cm}$, as greater than $\sim 50,000{ }^{14} \mathrm{C}$ yr B.P. The upper two paleosols at Halfway House are overlain by loess that hosts the modern soil complex. This loess has a ${ }^{10} \mathrm{Be}$ age estimate of $\sim 17,000 \mathrm{yr}$ at its base and $\sim 8000 \mathrm{yr}$ in its upper part, at the base of the modern soil. Berger (2003) reports a TL age of $\sim 11,000 \mathrm{yr}$ for loess below the modern soil at Halfway House, which is in broad agreement with the ${ }^{10} \mathrm{Be}$ age estimates. However, if the ${ }^{10} \mathrm{Be}$ age estimate of $\sim 17,000 \mathrm{yr}$ at the base of the uppermost loess at $\sim 400 \mathrm{~cm}$ is correct, then the radiocarbon age of $>50,300{ }^{14} \mathrm{C} \mathrm{yr}$ B.P. (WW-5445) for charcoal in the subjacent paleosol indicates that a significant unconformity exists at this depth in the Halfway House section.

\section{GOLD HILL}

The Gold Hill locality has the oldest loesses of which we are aware in the Fairbanks area. Based on the presence of the PH tephra between 1700 and $1800 \mathrm{~cm}$ depth, above a major paleosol complex, the second-oldest loess in the portion of the Gold Hill section we studied could be almost $600,000 \mathrm{yr}$ old (Fig. 5). An unnamed and undated tephra occurs within the loess above this, between 1000 and $1100 \mathrm{~cm}$ depth. Between 770 and $670 \mathrm{~cm}$ depth, there is a well-expressed paleosol complex, and the Dome tephra is found in the uppermost part of this complex. Because of this stratigraphic position, we correlate this paleosol complex with the last interglacial paleosol at Eva Creek. Between $\sim 200$ and $\sim 300 \mathrm{~cm}$ depth, there is a complex of four paleosols with humic acid radiocarbon ages ranging from $\sim 39,020 \pm 1420{ }^{14} \mathrm{C}$ yr B.P. (lowermost) to $33,280 \pm 680{ }^{14} \mathrm{C}$ yr B.P. (uppermost). These correspond to calibrated ages of $\sim 44,000$ and $\sim 36,000 \mathrm{yr}$ B.P., respectively. Nevertheless, based on the differences at Halfway House between humic acid (Muhs et al., 2003a) and charcoal (this study) radiocarbon ages, the paleosol complex between $\sim 200 \mathrm{~cm}$ and $\sim 300 \mathrm{~cm}$ depth at Gold Hill could very well be $>50,000 \mathrm{yr}$ B.P. Loess in the uppermost $\sim 200 \mathrm{~cm}$ of the section has ${ }^{10} \mathrm{Be}$ age estimates of $\sim 13,000 \mathrm{yr}$ at its base and $\sim 8000 \mathrm{yr}$ in its uppermost part, just below the modern soil. These age estimates are in broad agreement with the ${ }^{10} \mathrm{Be}$ ages of the uppermost loess at Halfway House.

\section{CHENA HOT SPRINGS ROAD}

The Chena Hot Springs Road locality (Fig. 6) is located just east of Fairbanks (Fig. 2). At this section, the lowermost loess, from a depth of $\sim 750$ to $\sim 1150 \mathrm{~cm}$, contains no dateable material that we could find. The Dome tephra, however, is found between $\sim 700$ and $\sim 750 \mathrm{~cm}$ and is older than $55,900{ }^{14} \mathrm{C}$ yr B.P., based on charcoal found near it (Muhs et al., 2003a). This tephra is overlain by three paleosols developed in thin loess between $\sim 600$ and $\sim 700 \mathrm{~cm}$, the uppermost of which has a humic acid radiocarbon age of $37,050 \pm 390{ }^{14} \mathrm{C}$ yr B.P. $(\sim 42,000 \mathrm{cal}$ yr B.P.). This is almost certainly a minimum estimate, because nearly the same age was obtained for humic acids in the lower of two paleosols found between depths of $\sim 200$ and $\sim 300 \mathrm{~cm}$. Two more paleosols are found between $\sim 100$ and $\sim 200 \mathrm{~cm}$ depth, with humic acid ages of $\sim 30,000{ }^{14}$ C yr B.P. $(\sim 35,000$ cal yr B.P.). Finally, loess-hosted charcoal, just below the modern soil in the exposure on the south side of the road, gave a radiocarbon age of $8250 \pm 30{ }^{14} \mathrm{C}$ yr B.P. ( $\sim 9200$ cal yr B.P.), in broad agreement with the ${ }^{10} \mathrm{Be}$ age estimates of $\sim 8000 \mathrm{yr}$ below the modern soils at Gold Hill and Halfway House.

\section{BIRCH HILL}

We could find little dateable material at any depth at the Birch Hill section (Fig. 7), a locality also found just east of Fairbanks (Fig. 2). Charcoal in the lowest of three paleosols, at a depth of $\sim 380 \mathrm{~cm}$, gave a radiocarbon age of $41,600 \pm 1200{ }^{14} \mathrm{C}$ yr B.P., corresponding to a calibrated age of $\sim 46,000 \mathrm{yr}$ B.P. Humic acids from the uppermost of these three paleosols gave an 

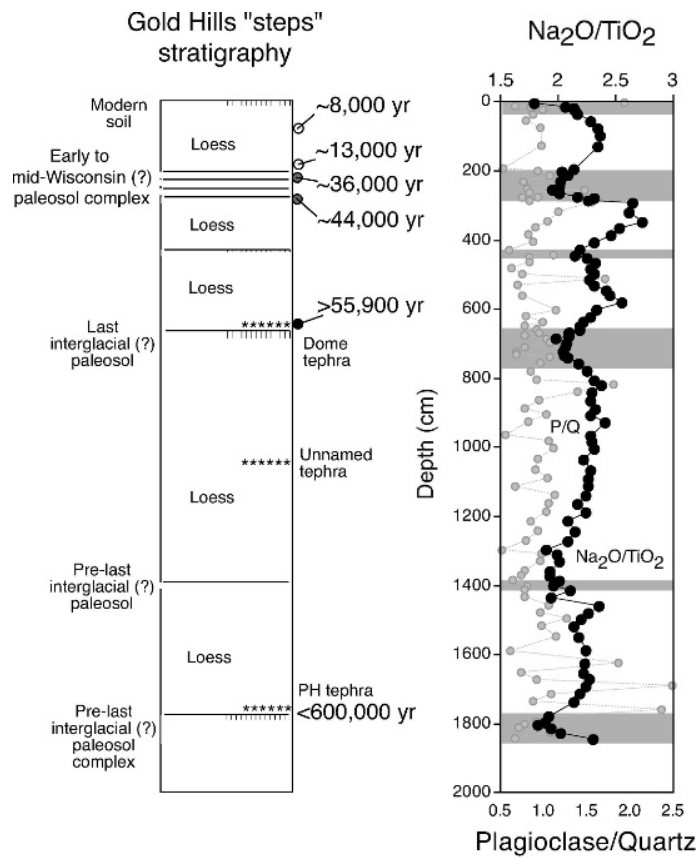

$\mathrm{SiO}_{2} / \mathrm{TiO}_{2}$

$\begin{array}{lllll}65 & 70 & 75 & 80 & 85\end{array}$

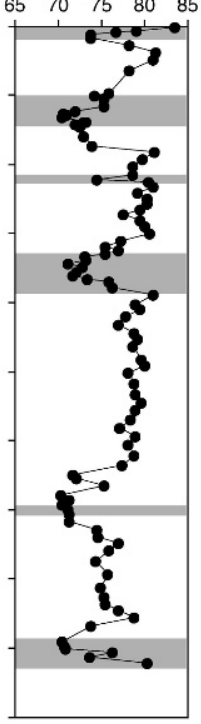

$\mathrm{CaO} / \mathrm{TiO}_{2}$

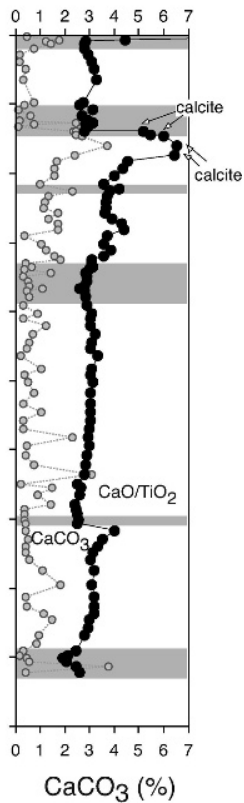

FIGURE 5. Loess stratigraphy, radiocarbon ages, selected ${ }^{10} \mathrm{Be}$ age estimates, and possible correlations (Muhs et al., 2003a) at the Gold Hill section; fission-track age estimate for the $\mathrm{PH}$ tephra is from Westgate et al. (1990). Open circles are ${ }^{10} \mathrm{Be}$ age estimates, gray-filled circles are radiocarbon ages of humic acid extractions, black-filled circle is radiocarbon age of charcoal. Also shown are plots of $\mathrm{Na}_{2} \mathrm{O} / \mathrm{TiO}_{2}$, plagioclase/ quartz, $\mathrm{SiO}_{2} / \mathrm{TiO}_{2}, \quad \mathrm{CaO} / \mathrm{TiO}_{2}$, and $\mathrm{CaCO}_{3}$ in the section. Gray shades mark paleosols. age of $27,580 \pm 220{ }^{14} \mathrm{C}$ yr B.P. (Muhs et al., 2003a), corresponding to a calibrated age of $\sim 33,000 \mathrm{yr}$ B.P.

\section{Mineralogy}

The bulk mineralogy of central Alaskan loess is similar to loesses found elsewhere. Minerals identified by XRD in the present study include quartz, mica, chlorite, plagioclase, and small amounts of K-feldspar. A few samples from the Gold Hill and Halfway House sections have calcite, which we discuss in more detail below. Mica, which appears to be mostly muscovite, is abundant in central Alaskan loess and is easily visible under magnification or even in hand samples. Although central Alaskan loess has both K-feldspar and plagioclase, plagioclase is by far the more abundant of the two minerals. XRD patterns, particularly the peak at around $29.7^{\circ} 2 \theta$ (Moore and Reynolds, 1989) indicate that plagioclase has a dominantly sodic, rather than calcic composition. The relative abundance of quartz, plagioclase, and $\mathrm{K}$-feldspar in central Alaskan loess is, overall, very similar to that found in midcontinental North American loesses. A major difference between Alaskan loess and midcontinental loesses is that the latter have much higher abundances of carbonate minerals (calcite and dolomite).

\section{CHEMICAL WEATHERING}

If chemical weathering has been important in soils derived from central Alaskan loess, the minerals most prone to alteration should be feldspars, micas, clay minerals, and carbonates. Major elements in these minerals will be lost as chemical weathering proceeds, but to ascertain such loss, mobile elements must be indexed to an element that is unlikely to experience loss in
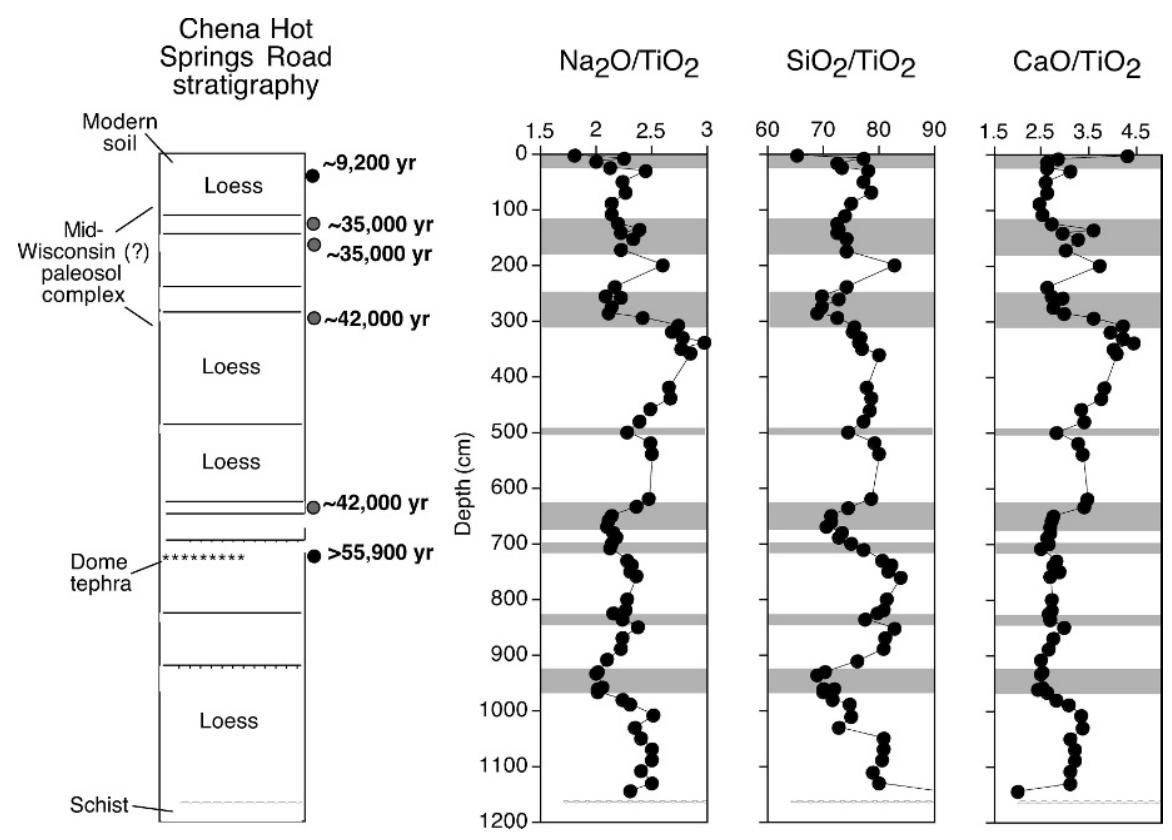

$\mathrm{CaO} / \mathrm{TiO}_{2}$

FIGURE 6. Loess stratigraphy, radiocarbon ages, and possible correlations (Muhs et al., 2003a) at the Chena Hot Springs Road section. Gray-filled circles are radiocarbon ages of humic acid extractions, black-filled circles are radiocarbon ages of charcoal. Also shown are plots of $\mathrm{Na}_{2} \mathrm{O} / \mathrm{TiO}_{2}$, $\mathrm{SiO}_{2} / \mathrm{TiO}_{2}$, and $\mathrm{CaO} / \mathrm{TiO}_{2}$ in the section. Gray shades mark paleosols. 

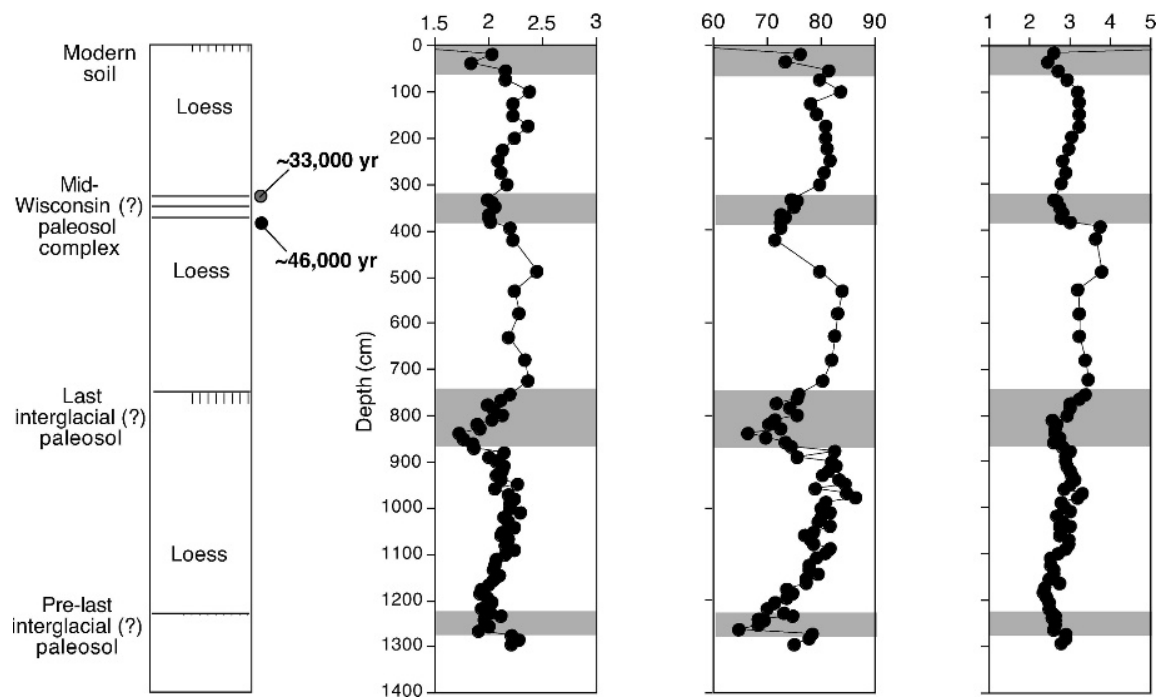

FIGURE 7. Loess stratigraphy, radiocarbon ages, and possible correlations (Muhs et al., 2003a) at the Birch Hill section. Grayfilled circle is radiocarbon age of a humic acid extraction, blackfilled circle is a radiocarbon age of charcoal. Also shown are plots of $\mathrm{Na}_{2} \mathrm{O} / \mathrm{TiO}_{2}, \mathrm{SiO}_{2} / \mathrm{TiO}_{2}$, and $\mathrm{CaO} / \mathrm{TiO}_{2}$ in the section. Gray shades mark paleosols.

solution. Because of their relative immobility under most nearsurface conditions, $\mathrm{Ti}$ and $\mathrm{Zr}$ (usually expressed as $\mathrm{TiO}_{2}$ and $\mathrm{ZrO}_{2}$ ) are useful as stable index elements (Birkeland, 1999; Muhs et al., $2001 b)$. Sodic plagioclase, or albite $\left(\mathrm{NaAlSi}_{3} \mathrm{O}_{8}\right)$ is the main carrier of $\mathrm{Na}_{2} \mathrm{O}$ unless there are significant amounts of hornblende present. Thus, a geochemical proxy for the degree of sodic plagioclase alteration is $\mathrm{Na}_{2} \mathrm{O} / \mathrm{TiO}_{2}$ (see Muhs et al., 2001b, for examples from loess-derived soils elsewhere). Alteration of either mica or K-feldspar results in loss of $\mathrm{K}$, which can be measured by $\mathrm{K}_{2} \mathrm{O} / \mathrm{TiO}_{2}$. Because plagioclase, $\mathrm{K}$-feldspar, and mica are all silicates, alteration of these minerals by hydrolysis results in production of soluble silicic acid and ultimately loss of $\mathrm{SiO}_{2}$. Therefore, lower ratios of $\mathrm{Na}_{2} \mathrm{O} / \mathrm{TiO}_{2}$ and $\mathrm{K}_{2} \mathrm{O} / \mathrm{TiO}_{2}$, if they reflect plagioclase, mica, or $\mathrm{K}$-feldspar losses, should be accompanied by lower values of $\mathrm{SiO}_{2} / \mathrm{TiO}_{2}$. Weathering of aluminosilicate clay minerals such as smectite, chlorite, and clay-sized mica should also be reflected in lower $\mathrm{SiO}_{2} / \mathrm{TiO}_{2}$ values. If loess deposits originally contained carbonates, loss of these minerals is reflected in lower $\mathrm{CaO} / \mathrm{TiO}_{2}$ and $\mathrm{MgO} / \mathrm{TiO}_{2}$ values.

Loess in the Fairbanks area shows a fair amount of compositional variability, based on $\mathrm{Ti} / \mathrm{Zr}$ ratios and comparisons with midcontinental loess (Muhs et al., 2003a). More detailed studies by Muhs and Budahn (2006) showed that loess in the Fairbanks area is not derived solely from the nearby Tanana River, but also from the Yukon River to the north and, to a lesser extent, the Nenana River to the south. Thus, it is likely that at any given locality, initial composition of the loess around Fairbanks was a temporally varying function of the relative inputs of different river sediments. We consider that the subjacent loess is the best approximation of initial composition for any given paleosol. Nevertheless, even this simple assumption needs to be qualified, because Begét (1996) and Muhs et al. (2003a) presented evidence showing that periods of soil formation in central Alaska are accompanied by continued, lower-flux-rate loess deposition.

\section{SILICATE MINERAL DEPLETION}

Geochemical data indicate that modern soils and many paleosols in Fairbanks-area loesses have experienced measurable degrees of plagioclase loss. At Halfway House, we estimated ratios of bulk-sample plagioclase to quartz (P/Q), using XRD peak intensity. Quartz here is used as a stable index mineral. Results indicate generally lower P/Q values in the modern, and hypothesized early-to-mid-Wisconsin and last-interglacial paleosols compared to the subjacent loess (Fig. 4). Geochemical data show fair agreement with the mineralogical data. $\mathrm{Na}_{2} \mathrm{O} / \mathrm{TiO}_{2}$ in loess is generally between about 2.2 and 2.8. However, the modern soil shows considerably lower $\mathrm{Na}_{2} \mathrm{O} / \mathrm{TiO}_{2}$ compared to the subjacent loess, as do the hypothesized early-to-mid-Wisconsin and last-interglacial paleosols. The hypothesized last-interglacial paleosol has the lowest $\mathrm{Na}_{2} \mathrm{O} / \mathrm{TiO}_{2}$ of the entire section, and values increase only gradually with greater depth. This observation suggests relatively low rates of loess deposition or, less likely, mixing of a once-thicker paleosol with underlying loess. The thin, minimally developed paleosols below $\sim 900 \mathrm{~cm}$ depth do not show much evidence of $\mathrm{Na}$ loss by comparison with the younger paleosols.

At Eva Creek, the last interglacial paleosol, the hypothesized early-to-mid-Wisconsin paleosols, and the modern soil have lower $\mathrm{Na}_{2} \mathrm{O} / \mathrm{TiO}_{2}$ than subjacent loess, indicating plagioclase loss (Fig. 3). Muhs et al. (2001a) made a similar interpretation for the last interglacial paleosol at Eva Creek (lower) and a different modern soil at the Eva Creek (upper) site. However, the new data presented here for the early-to-mid-Wisconsin paleosols and the modern soil at Eva Creek (lower) indicate plagioclase loss in these soils as well.

At both the Eva Creek and Halfway House sections, $\mathrm{SiO}_{2} /$ $\mathrm{TiO}_{2}$ values track $\mathrm{Na}_{2} \mathrm{O} / \mathrm{TiO}_{2}$ fairly closely (Figs. 3 and 4). At both sections, the lowest values of $\mathrm{SiO}_{2} / \mathrm{TiO}_{2}$ are in the modern soil and hypothesized early-to-mid-Wisconsin and last-interglacial paleosols. We interpret loss of both $\mathrm{Na}$ and $\mathrm{Si}$ relative to $\mathrm{Ti}$ in these soils as complementary evidence of plagioclase depletion. There are two exceptions to this trend at depth in the Halfway House section, however. Just above the Old Crow tephra, higher $\mathrm{SiO}_{2} / \mathrm{TiO}_{2}$ may reflect some mixing with glass in the subjacent tephra. A higher $\mathrm{SiO}_{2} / \mathrm{TiO}_{2}$ value in the paleosol at $\sim 1050 \mathrm{~cm}$ may be the result of mixing with the underlying schist. At Halfway House, $\mathrm{K}_{2} \mathrm{O} / \mathrm{TiO}_{2}$ (not shown in Fig. 4) does not exhibit a systematic pattern of depletion in paleosols compared to subjacent loesses, suggesting little or no loss of K-bearing minerals such as mica or K-feldspar.

The Gold Hill section has the longest and perhaps one of the most complete records of loess fall, soil formation, and chemical weathering yet discovered in central Alaska (Fig. 5). As at 
Halfway House, $\mathrm{P} / \mathrm{Q}$ values show fair agreement with $\mathrm{Na}_{2} \mathrm{O} / \mathrm{TiO}_{2}$, and lower values of both are found in the modern soil and paleosols. Unaltered loess has a highly variable range of $\mathrm{Na}_{2} \mathrm{O}$ / $\mathrm{TiO}_{2}$, but is generally between 2.2 and 2.7, similar to Eva Creek and Halfway House. However, all paleosols have $\mathrm{Na}_{2} \mathrm{O} / \mathrm{TiO}_{2}$ lower than 2.0, with the exception of the one at $\sim 430 \mathrm{~cm}$, which is 2.1. As with Eva Creek and Halfway House, $\mathrm{Na}_{2} \mathrm{O} / \mathrm{TiO}_{2}$ is tracked closely by $\mathrm{SiO}_{2} / \mathrm{TiO}_{2}$, which supports an interpretation of plagioclase depletion. At Gold $\mathrm{Hill}, \mathrm{K}_{2} \mathrm{O} / \mathrm{TiO}_{2}$ (not shown in Fig. 5) exhibits a pattern of enrichment in surface soil horizons and depletions in lower soil horizons, compared to subjacent loesses, with the exception of the paleosol complex between $\sim 200$ and $\sim 300 \mathrm{~cm}$. We suspect that although some overall $\mathrm{K}$ loss (from mica?) has taken place in all soils, some $\mathrm{K}$ has been retained in surface horizons, perhaps due to biocycling.

At the Chena Hot Springs Road section, $\mathrm{Na}_{2} \mathrm{O} / \mathrm{TiO}_{2}$ in all paleosols is lower than in subjacent loesses (Fig. 6). Most unaltered loesses have $\mathrm{Na}_{2} \mathrm{O} / \mathrm{TiO}_{2}$ around 2.5 and some range up to 3 . In contrast, paleosols have $\mathrm{Na}_{2} \mathrm{O} / \mathrm{TiO}_{2}$ that are always less than 2.5 and several soils (the modern soil, the lowest part of the hypothesized mid-Wisconsin paleosol complex, and the paleosols at $\sim 650$ and $\sim 950 \mathrm{~cm}$ ) have values of only $\sim 2.0$. The same four paleosols have the lowest $\mathrm{SiO}_{2} / \mathrm{TiO}_{2}$ compared to the subjacent loess. $\mathrm{K}_{2} \mathrm{O} / \mathrm{TiO}_{2}$ at Chena Hot Springs Road (not shown) shows a pattern similar to that at Gold Hill, with paleosols exhibiting some depletion in their lower parts and some enrichment in their upper parts.

The Birch Hill section shows a pattern of probable plagioclase loss similar to the Chena Hot Springs Road section, although, overall, $\mathrm{Na}_{2} \mathrm{O} / \mathrm{TiO}_{2}$ is lower in both loesses and paleosols compared to the other loess sections (Fig. 7). Unaltered loess at Birch Hill has values generally between 2.2 and 2.5, but the modern soil and all three paleosols have values between 1.6 and 1.9. As with the other sections, the depth variations for $\mathrm{Na}_{2} \mathrm{O} / \mathrm{TiO}_{2}$ are paralleled by those for $\mathrm{SiO}_{2} / \mathrm{TiO}_{2} . \mathrm{K}_{2} \mathrm{O} / \mathrm{TiO}_{2}$ at Birch Hill (not shown) exhibits a pattern similar to those at Gold Hill and Chena Hot Springs Road. The upper parts of paleosols have relatively high values, usually as high as the underlying loess, but lower paleosol horizons (or the very upper parts of the loess) show depletions relative to deeper, unaltered loess.

\section{CARBONATE MINERAL DEPLETION}

Fairbanks-area loesses do not contain high amounts of carbonate minerals (Péwé, 1975). This is confirmed by recent chemical analyses showing low abundances of $\mathrm{CaO}$ and $\mathrm{MgO}$ compared to glaciogenic loess from some North American midcontinent localities, such as Illinois (Muhs et al., 2003a). However, $\mathrm{CaO}$ and $\mathrm{MgO}$ contents of central Alaska loess are as high or higher as non-glaciogenic loess from other midcontinent localities, such as eastern Nebraska.

Nevertheless, measurements of $\mathrm{CaCO}_{3}$ abundance at the Halfway House and Gold Hill loess sections show that small but detectable amounts of carbonate are present (Figs. 4 and 5). $\mathrm{CaCO}_{3}$ content is rarely over $3 \%$, and most samples are less than $2 \%$. Because the estimates of $\mathrm{CaCO}_{3}$ content for these samples are based on gas evolution over only $\sim 5$ minutes, it is likely that dolomite, if present, would not be detected; thus, these are essentially measures of calcite content. Values of $\mathrm{CaO} / \mathrm{TiO}_{2}$ track $\mathrm{CaCO}_{3}$ abundances fairly closely at Halfway House and Gold Hill (Figs. 4 and 5). Both $\mathrm{Mg}$ and $\mathrm{Sr}$, elements that substitute for $\mathrm{Ca}$, parallel the carbonate curves (e.g., Eva Creek, Fig. 3). Thus, we consider $\mathrm{CaO} / \mathrm{TiO}_{2}$ to be a reasonable proxy for carbonate abundance.
Abundance of carbonates, as shown by $\mathrm{CaCO}_{3}$ and $\mathrm{CaO} /$ $\mathrm{TiO}_{2}$, do not always show systematic differences between loess and paleosols at Halfway House and Gold Hill (Figs. 4 and 5). At Halfway House, in general, paleosols have lower $\mathrm{CaCO}_{3}$ and $\mathrm{CaO} /$ $\mathrm{TiO}_{2}$ than subjacent loesses. Nevertheless, higher values are found in the middle of the modern soil complex and in the upper part of the early-to-mid-Wisconsin paleosol complex. At Gold Hill, some of the highest values are found in the upper part of the modern soil (perhaps from biocycling of calcium), the lowermost part of the early-to-mid-Wisconsin paleosol complex, and the loess in which the latter soil is developed. In the lowermost part of this paleosol complex, secondary calcite is visible in the field as faint, white coatings on ped faces.

For the other three loess sections, we use $\mathrm{CaO} / \mathrm{TiO}_{2}$ as a proxy for carbonate content. At Eva Creek, values are generally lower in the modern soil and the hypothesized early-to-midWisconsin paleosols compared to subjacent loess (Fig. 3). We note, however, that the modern soil has higher $\mathrm{CaO} / \mathrm{TiO}_{2}$ in the $\mathrm{O}$ horizon, again possibly due to biocycling. In contrast, both the loess above and to a lesser extent the loess below the lastinterglacial paleosol have $\mathrm{CaO} / \mathrm{TiO}_{2}$ and $\mathrm{MgO} / \mathrm{TiO}_{2}$ that are not much different from the paleosol itself, and all values are lower than in the loess below the modern soil. At Chena Hot Springs Road and Birch Hill, high $\mathrm{CaO} / \mathrm{TiO}_{2}$ is also found in the modern soil $\mathrm{O}$ horizons (Figs. 6 and 7). In the paleosols at both of these sections, $\mathrm{CaO} / \mathrm{TiO}_{2}$ values are generally lower than in the subjacent loesses, but differences are not always dramatic.

It is likely that central Alaskan loess was originally moderately-to-highly calcareous. Muhs and Budahn (2006) estimated that Fairbanks-area loesses of late Quaternary age are derived from river sources as follows: $62-43 \%$ Tanana River silt, 36-20\% Yukon River silt, and 21-12\% Nenana River silt. Eberl (2004) reported that Yukon River sediments have $\sim 10 \%$ carbonate and Tanana River sediments have $\sim 3 \%$ carbonate. The carbonate includes calcite and dolomite in sediment from both rivers. The relative difference in sediment carbonate content between the two rivers agrees well with our own observations. Reactions of river sediment to dilute $\mathrm{HCl}$ in the field show that modern Tanana River sediments are strongly effervescent, and Yukon River sediments are strongly to violently effervescent. The geochemical analyses of Muhs and Budahn (2006) for river sediments do not include $\mathrm{TiO}_{2}$, but do include $\mathrm{CaO}$ and $\mathrm{ZrO}_{2}$. Zirconium, as with titanium, can be used as an immobile index element. We determined $\mathrm{CaO} / \mathrm{ZrO}_{2}$ for the five loess sections studied here, in order to compare them with the river sediment sources.

$\mathrm{CaO} / \mathrm{ZrO}_{2}$ values show that even what we have described as "unaltered" loess in the field has considerable carbonate depletion, compared to the silt fractions $(53-2 \mu \mathrm{m})$ of the river source sediments (Fig. 8). Almost all of the loess units and paleosols at Chena Hot Springs Road and Birch Hill have $\mathrm{CaO} /$ $\mathrm{ZrO}_{2}$ lower than the lowest values of both Tanana River and Yukon River loess. Only the loess immediately below the hypothesized mid-Wisconsin paleosol complex at Birch Hill has somewhat higher values that fall within the range of both river silts. At Gold Hill, most of the loess samples have $\mathrm{CaO} / \mathrm{ZrO}_{2}$ lower than both river silts, again with the exception of the lower part of the hypothesized early-to-mid-Wisconsin paleosol complex and the loess just below it. At Eva Creek, the uppermost loesses (from the surface to $400 \mathrm{~cm}$ and around $1000 \mathrm{~cm}$ ) have $\mathrm{CaO} / \mathrm{ZrO}_{2}$ that fall within the range of Tanana River silts, but the lowermost loesses (below $\sim 1900 \mathrm{~cm}$ ) have values that are mostly lower than the river silts. The hypothesized early-to-mid-Wisconsin paleosolloess complex at Eva Creek, at $\sim 1000$ to $1100 \mathrm{~cm}$, has relatively 


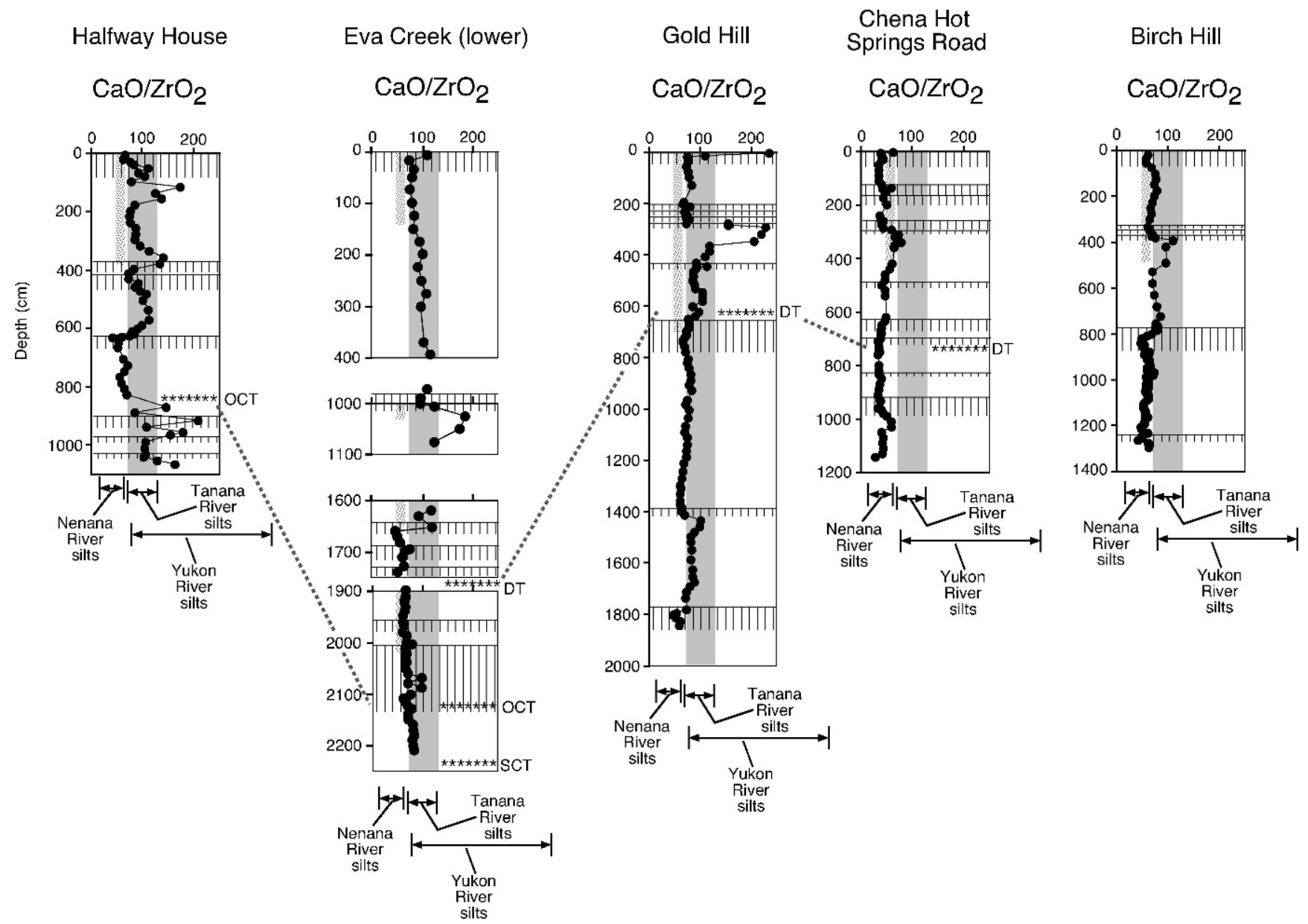

FIGURE 8. Plots of $\mathrm{CaO} / \mathrm{ZrO}_{2}$ for the Halfway House, Eva Creek, Gold Hill, Chena Hot Springs Road, and Birch Hill loess sections; hachures represent modern soils and paleosols. Dashed gray lines correlate parts of sections where tephras are found (DT, Dome tephra; OCT, Old Crow tephra; SCT, Sheep Creek tephra). Also shown are ranges of the loess source sediments (silt fractions of the Tanana River, Yukon River, and Nenana River; data from Muhs and Budahn, 2006).

high $\mathrm{CaO} / \mathrm{ZrO}_{2}$, similar to Gold Hill. At Halfway House, $\mathrm{CaO} /$ $\mathrm{ZrO}_{2}$ within "unaltered" loess shows three ranges of values corresponding to depth intervals of $\sim 100-350 \mathrm{~cm}, \sim 460-600 \mathrm{~cm}$, and $\sim 650-900 \mathrm{~cm}$. The upper two depth intervals have $\mathrm{CaO} / \mathrm{ZrO}_{2}$ that fall within the range of Tanana River silts and the lower part of the range of Yukon River silts. The lowest depth interval, however, has $\mathrm{CaO} / \mathrm{ZrO}_{2}$ that is mostly below the range of both groups of river sediments. An exception to this generalization is that the uppermost part of the upper depth interval, just below the modern soil, has relatively high $\mathrm{CaO} / \mathrm{ZrO}_{2}$, well within the range of Yukon River silts and actually higher than the range of Tanana River silts. Also, parts of the mid-Wisconsin paleosol complex and the loess just above it have high $\mathrm{CaO} / \mathrm{ZrO}_{2}$. XRD analyses indicate that calcite is present in this zone (Fig. 4).

\section{CLAY MINERAL DEPLETION}

For identification of clay minerals, we follow guidelines in Moore and Reynolds (1989). Mica has characteristic peaks at $10.1 \AA$ and $5 \AA$, which are unaffected by ethylene glycol solvation and heat

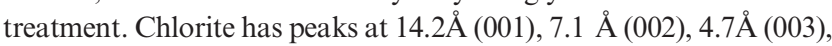
and $3.55 \AA(004)$, in both air-dry and glycolated states. Kaolinite has peaks at $7.1 \AA(001)$ and $3.55 \AA(002)$. Heat treatment causes the chlorite (002), (003), and (004) peaks and both kaolinite peaks to disappear or diminish greatly, whereas the (001) chlorite peak increases in intensity. When air-dry or glycolated, (001) and (003) chlorite peaks in central Alaskan loess are less intense than (002) and (004) peaks, suggesting that the chlorite is Fe-rich (in contrast to an erroneous statement to the opposite by Muhs et al., 2003a, p. 1955).

In order to assess the degree of weathering of clay minerals in central Alaskan loess and paleosols, we first determined the clay mineralogy of Tanana and Yukon River sediments, the primary sources of loess. Both rivers at all localities have a similar suite of clay-sized minerals, consisting of phyllosilicates (smectite, chlorite, mica, and kaolinite) and primary rock-forming minerals (quartz, plagioclase, and possibly K-feldspar) (Fig. 9). Of these, chlorite and mica appear to be the most abundant species. Nevertheless, all samples have prominent smectite peaks that are symmetrical when glycolated, centering on $17 \AA$. Overall, the clay mineral suite we observe for both rivers is similar to that reported by Eberl (2004).

Modern soils in the Fairbanks area have different clay mineral suites, both from locality to locality and in different horizons of the same soil. At Birch Hill, the $\mathrm{C}$ horizon has a clay mineralogy pattern that looks much like Tanana and Yukon River sediments, with smectite, chlorite, mica, kaolinite, quartz, and plagioclase all present (Fig. 10). Moving upward through this profile, however, the mica, chlorite/kaolinite, and plagioclase peaks are more subdued, suggesting depletion of these minerals at shallower depths. Smectite peak heights are also diminished with shallower depths until the Bw1 and E horizons are reached, where peaks become prominent again. At Chena Hot Springs Road, mica and chlorite/kaolinite have prominent peaks in the $\mathrm{C}$ 


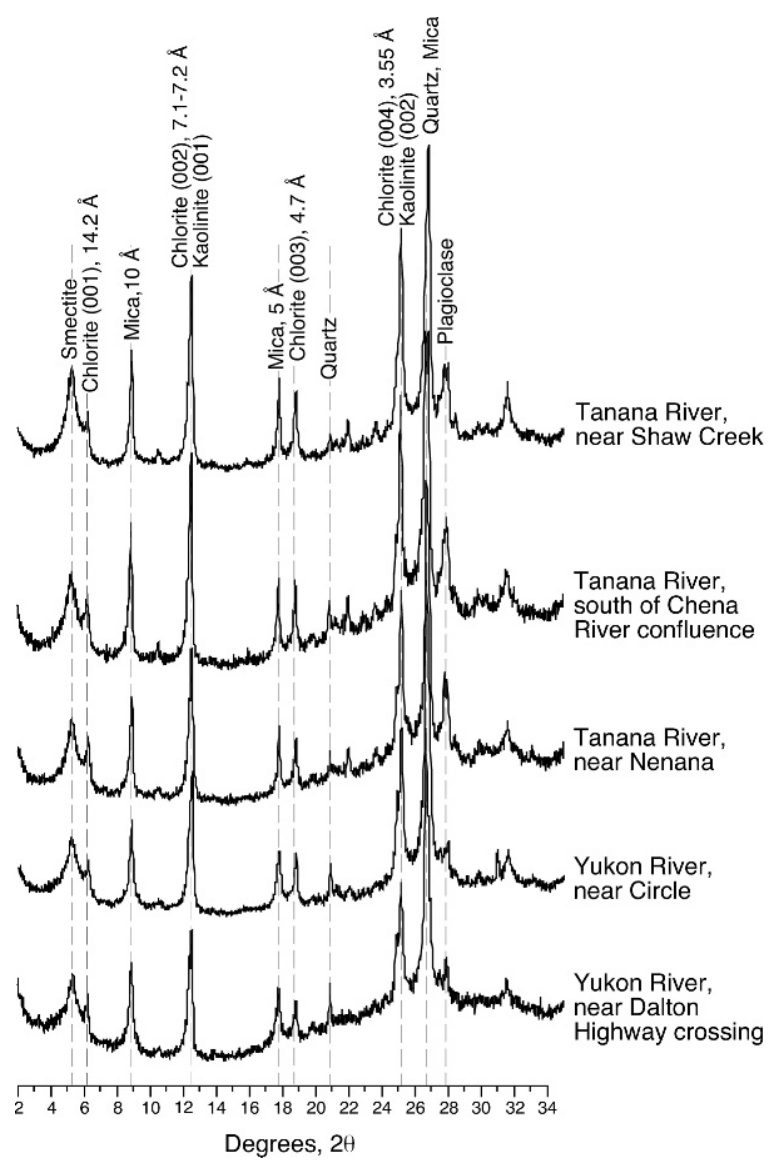

FIGURE 9. X-ray diffraction patterns (glycolated, oriented mounts) of clays from various localities of the Tanana and Yukon Rivers.

horizon; these peaks diminish in height in the shallower Bw2 and Bw1 horizons, but become prominent again in the still-shallower $\mathrm{E}$ and $\mathrm{O}$ horizons (Fig. 10). In this profile, smectite is absent, except for a very small peak in the E horizon. The modern soil at Halfway House has more subdued mica and chlorite/kaolinite peaks in the $\mathrm{B}$ horizon compared to the $\mathrm{C}$ horizon, and lacks smectite altogether, even in the $\mathrm{C}$ horizon (Fig. 11). Smectite is also lacking in the A, upper B, and lower B horizons of the modern soil at Gold Hill (Fig. 12).

Paleosols at Halfway House and Gold Hill show clay mineral suites similar to the modern soils at these localities, with one difference (Figs. 11 and 12). Mica and chlorite/kaolinite peaks are present in all horizons, which is similar to the modern soils at these localities. However, the (001) chlorite peak is missing in the lastinterglacial and pre-last-interglacial paleosols at both localities, and is very subdued in the early-to-mid-Wisconsin paleosols. Furthermore, where smectite is present (the last-interglacial and pre-last-interglacial paleosols at Gold Hill and the early-to-midWisconsin paleosol at Halfway House), it has a fairly broad (001) plateau rather than a sharp, symmetrical peak at $17 \AA$. This plateau is steep on its high-angle side and has a more gradual rise on its low-angle side. We interpret this observation to indicate that much of the smectite is poorly crystallized, highly altered, or has a random interstratification with other clay minerals.

A comparison of clay minerals in the loess and paleosols with those in the river sediments suggests that depletion of some clay minerals has probably taken place after loess deposition. The most obvious difference is that relatively pure smectite is present in all river sediments, but is absent in all loess and paleosol samples

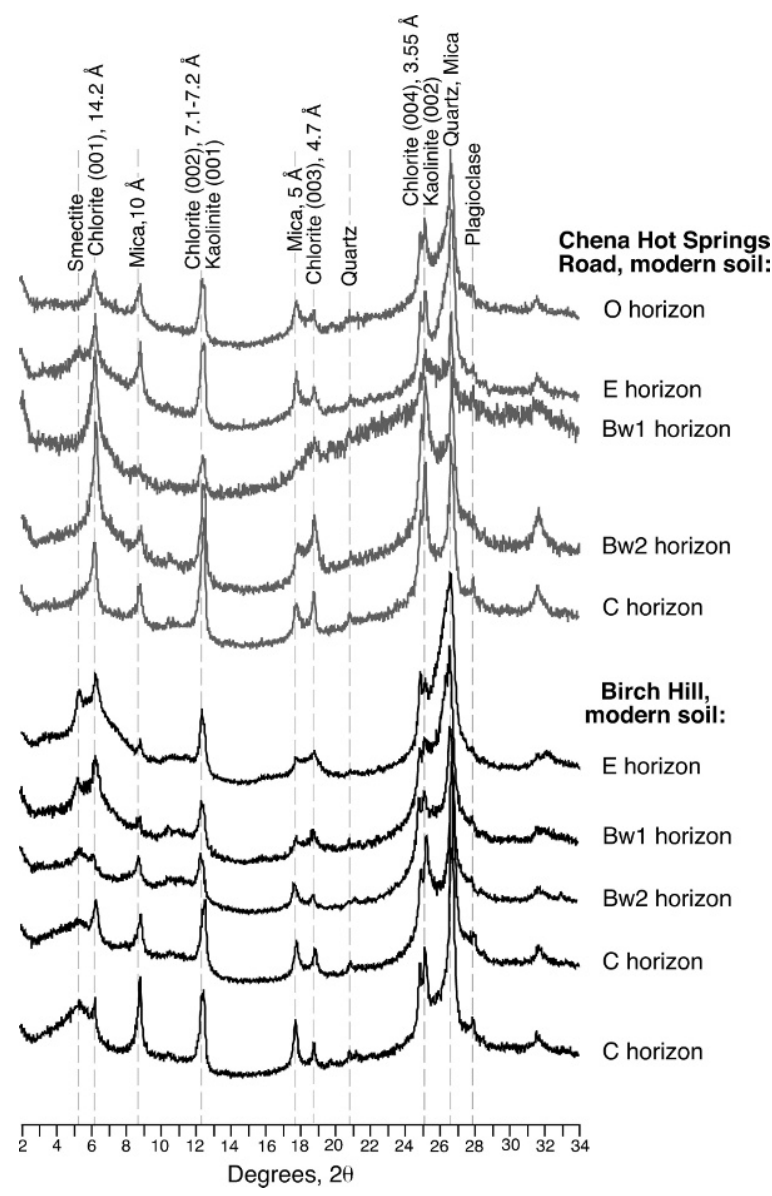

FIGURE 10. X-ray diffraction patterns (glycolated, oriented mounts) of clays from modern soils at the Chena Hot Springs Road and Birch Hill loess sections near Fairbanks.

studied. The hypothesized early-to-mid-Wisconsin paleosol at Halfway House and the possible last-interglacial and pre-last-interglacial paleosols at Gold Hill have some evidence of randomly interstratified clay minerals with a smectite component. However, relatively pure smectite is lacking in all soils, paleosols, and loesses studied. Another difference we note is that chlorite (001) peaks at $14.2 \AA$ are prominent in all river samples, but are absent or very subdued in all loesses and paleosols, suggesting some chlorite depletion after loess deposition. Finally, mica seems to show depletion in B horizons compared to C horizons in some soils and paleosols.

\section{Discussion}

\section{PRESENT AND PAST VEGETATION IN ALASKA BASED} ON POLLEN AND MACROFOSSIL EVIDENCE

Modern vegetation communities in Alaska are coastal forest, boreal forest, and several varieties of tundra, including herb tundra and shrub tundra (Ager and Brubaker, 1985; Edwards et al., 2000). Coastal forest is limited to southern and southeastern Alaska, whereas boreal forest is found in the interior of the region. Tundra is found in western Alaska, in northern Alaska (north of the Brooks Range), and at high elevations in mountain ranges that host forest at lower elevations. Although small areas of steppe vegetation can be found in parts of southwestern Yukon Territory (e.g., Laxton et al., 1996; Vetter, 2000), in Alaska they are rare and highly localized, and occur only in favorable microenvironments, such as steep, south-facing slopes with well-drained, silty-to-sandy soils (Edwards and Armbruster, 1989). 


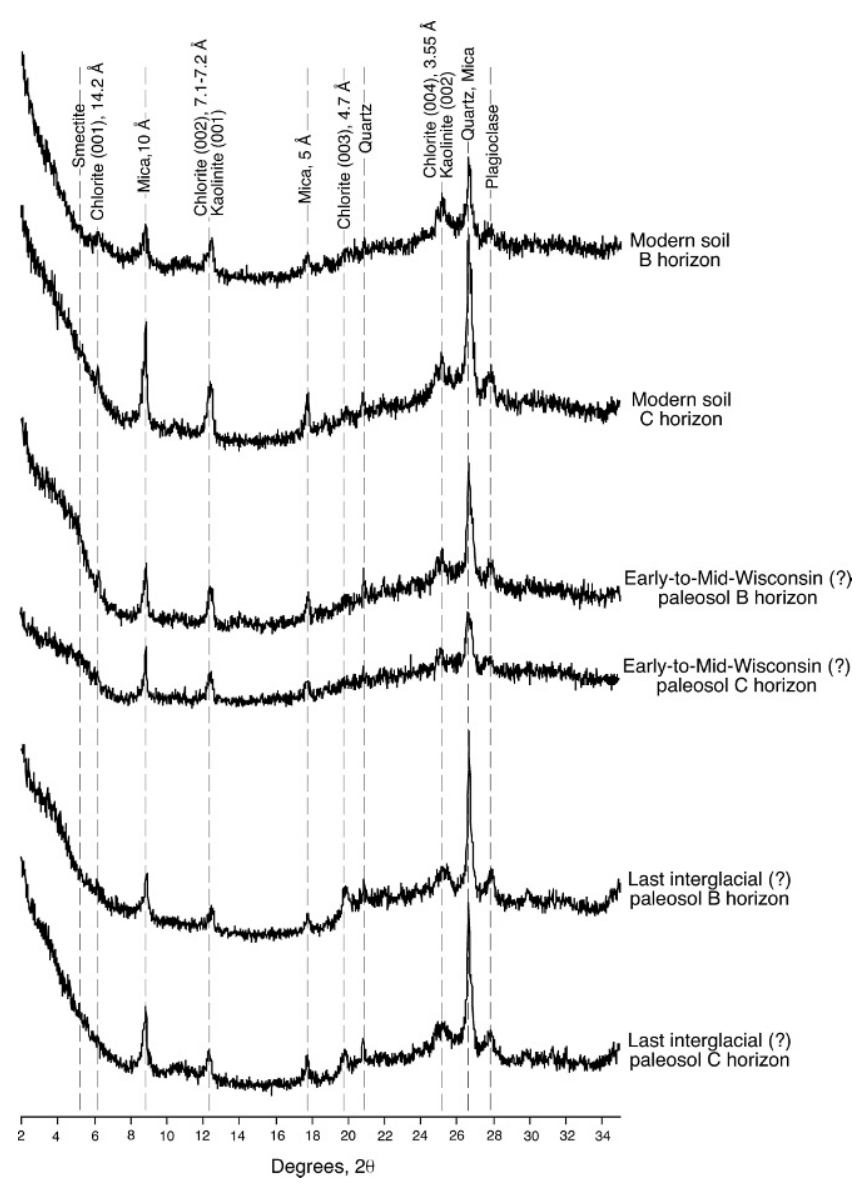

FIGURE 11. X-ray diffraction patterns (glycolated, oriented mounts) of clays from selected soils, paleosols, and loesses from the Halfway House section.

Geologic records of past vegetation with at least some age control exist for the last interglacial period, the mid-Wisconsin interstadial period or periods, the last (late Wisconsin) glacial period, and the Holocene. A climate and biome model simulated a grassland in interior Alaska and Yukon Territory for the last interglacial period, $\sim 125,000 \mathrm{yr}$ B.P. (Harrison et al., 1995). However, field studies indicate that the last interglacial period in much of central Alaska and Yukon was characterized by boreal forest with Picea and Betula, based on both pollen and plant macrofossil data (Péwé et al., 1997; Muhs et al., 2001a; Edwards et al., 2003). During the mid-Wisconsin interstadial period, pollen and macrofossil records suggest a succession (and perhaps a mosaic) of shrub tundra $(\sim 43,000$ to $\sim 39,000-38,000 \mathrm{yr}$ B.P. $)$, herb tundra $(\sim 39,000-38,000$ to $\sim 35,000$ yr B.P. $)$, Picea foresttundra $(\sim 35,000$ to $\sim 30,000$ yr B.P.), and herb tundra $(\sim 30,000$ to $\sim 25,000$ yr B.P.) in interior Alaska (Anderson and Lozhkin, 2001).

There are different interpretations of vegetation in Alaska and Yukon Territory during the late Wisconsin glacial period. Although grass concentrations are relatively high in last-glacial pollen records in Alaska, herb tundra is thought to have been the dominant vegetation type (Ager and Brubaker, 1985; Anderson and Brubaker, 1994; Edwards et al., 2000; Bigelow and Edwards, 2001). These same summaries show that shrub tundra followed herb tundra in the late glacial period, with Picea forest arriving in the Holocene. Full-glacial biotic records with plant macrofossils are rare in Alaska and Yukon Territory, but some that exist indicate that there could have been at least isolated patches of

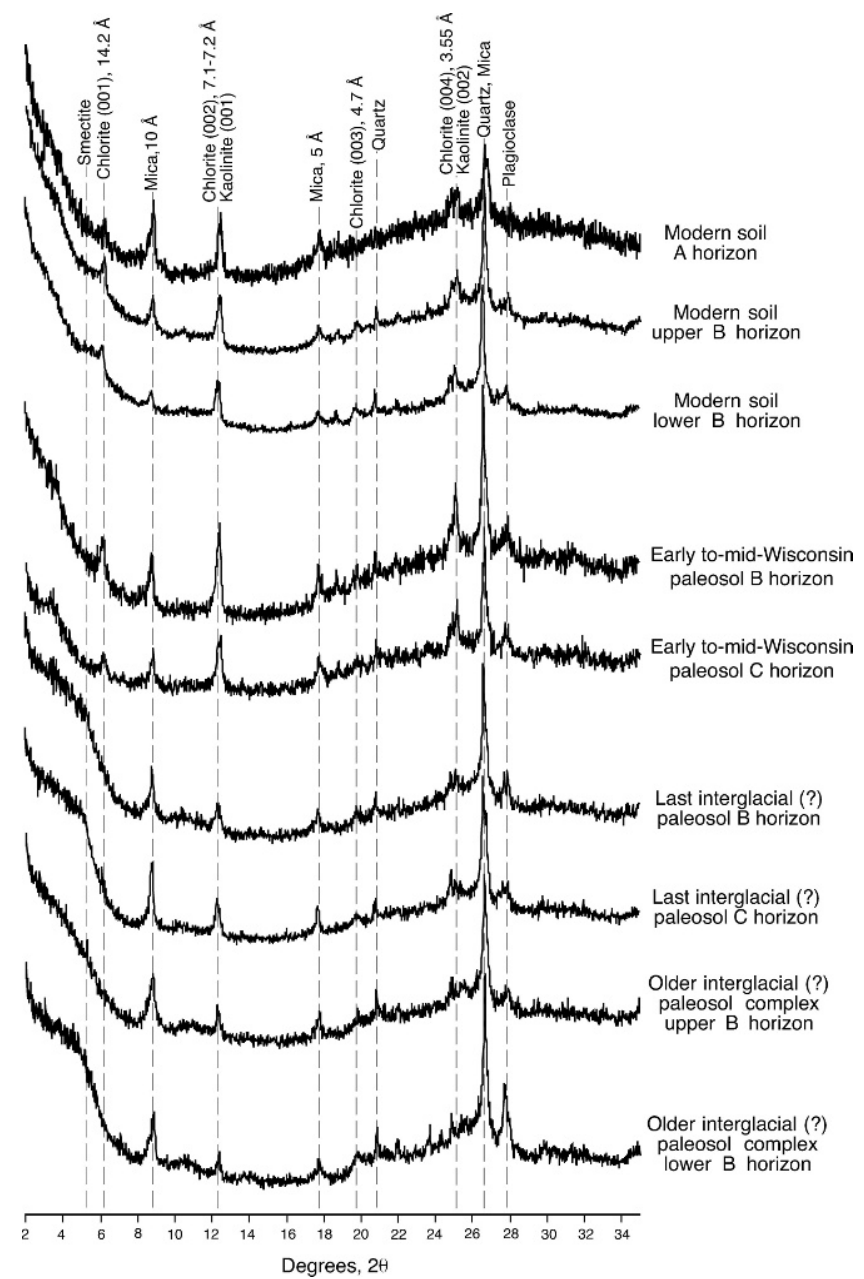

FIGURE 12. X-ray diffraction patterns (glycolated, oriented mounts) of clays from selected soils, paleosols, and loesses from the Gold Hill section.

steppe vegetation or steppe-tundra. Goetcheus and Birks (2001) described one such record from the Seward Peninsula as an environment of closed, dry, herb-rich tundra-grassland, dominated by grass, sedges, Kobresia, occasional Salix, and a moss cover. Studies of plant macrofossils by Sanborn et al. (2006) and Zazula et al. $(2005,2006,2007)$ indicate that steppe or steppe-tundra existed during last-glacial time at several localities in western Yukon Territory.

\section{VEGETATION CONTROL ON SOIL PH, MICROCLIMATE, AND MINERAL WEATHERING}

Acid conditions (soil pH values below 7.0) are a prerequisite for significant chemical weathering in soils. Soil $\mathrm{pH}$ is a function of vegetation, parent material composition, precipitation, and time since pedogenesis began. Vegetation is particularly important, because many plants produce organic acids that lower $\mathrm{pH}$ and enhance mineral weathering. Hence, even with a high-base status parent material, such as calcareous loess, acid-generating vegetation such as forest or acidic tundra can lower soil $\mathrm{pH}$ and result in mineral weathering. However, the reverse can also be observed, where calcareous loess inputs can influence $\mathrm{pH}$ and vegetation type. For example, in northern Alaska, soil $\mathrm{pH}$ and vegetation change as a function of downwind distance from rivers that are sources of calcareous loess (Walker and Everett, 1991). Neverthe- 
less, in Alaska, most modern soils that have developed under herb tundra, shrub tundra, boreal forest, or coastal forest are acidic (Rieger et al., 1979). In contrast to forest and tundra, grasses recycle base-forming cations, and soils developed under grassland tend to be non-acidic. Modern grasslands are very rare in Alaska, but occur in parts of Yukon Territory. Laxton et al. (1996) reported that loess and loess-derived soils under grass in Yukon Territory are alkaline.

In addition to vegetation influence on soil $\mathrm{pH}$, plant communities can bring about microclimatic effects that increase chemical weathering. In our introduction, we alluded to Guthrie (1990, 2001), who pointed out that although modern annual precipitation in central Alaska is low, certain microclimatic conditions enhance soil moisture. Boreal forest cover can reduce evaporation by shading during the summer months. The same forest cover can retain snow cover for longer periods in spring than would be the case with tundra or steppe vegetation, and extended periods of snow cover will tend to keep soil moisture high. Boreal forest can sometimes produce relatively thick soil $\mathrm{O}$ horizons that also minimize evaporative moisture loss from soils. Finally, forest cover, by reducing solar radiation to the soil surface, can help retain permafrost, which in turn can impede downward soil moisture loss. All of these factors can conceivably enhance chemical weathering in soils by retaining soil moisture for longer periods in summer than would be the case with some other vegetation type.

\section{CHEMICAL WEATHERING OF SILICATE MINERALS}

Results from our studies at all five loess sections indicate that most paleosols have experienced significant chemical weathering of silicate minerals. Modern soils and most buried soils at all five sections show lower $\mathrm{Na}_{2} \mathrm{O} / \mathrm{TiO}_{2}$ and $\mathrm{SiO}_{2} / \mathrm{TiO}_{2}$ than subjacent loess, which we believe reflects plagioclase depletion. Based on comparisons of $\mathrm{Na}_{2} \mathrm{O} / \mathrm{TiO}_{2}$ in soils versus unaltered loess at the sections studied, there has been up to $\sim 15-25 \%$ loss of $\mathrm{Na}_{2} \mathrm{O}$, relative to $\mathrm{TiO}_{2}$, in the modern soils and some of the buried soils.

The losses of $\mathrm{Na}_{2} \mathrm{O}$ in loess-derived soils and paleosols in central Alaska can be compared to those observed in loess-derived soils and paleosols of mid-latitude regions. Modern, midWisconsin, and last-interglacial loess-derived soils in China have experienced 1-25\% losses of $\mathrm{Na}_{2} \mathrm{O}$ (when normalized to $\mathrm{TiO}_{2}$ ), based on data presented by Gallet et al. (1996) and Jahn et al. (2001). The Chinese localities (Xining, Xifeng, Jixian, and Luochuan) have modern precipitation regimes ranging from less than $400 \mathrm{~mm} \mathrm{yr}^{-1}$ to slightly greater than $600 \mathrm{~mm} \mathrm{yr}^{-1}$. In the North American midcontinent, loess-derived soils in western and southern Illinois have $\mathrm{Na}_{2} \mathrm{O}$ losses (again normalized to $\mathrm{TiO}_{2}$ ) of $\sim 25-35 \%$ for modern soils and $\sim 50-65 \%$ for last-interglacial soils, based on data in Muhs et al. (2001b) and Grimley et al. (2003). Modern precipitation in this region is $\sim 900-1200 \mathrm{~mm}$ $\mathrm{yr}^{-1}$. The amounts of $\mathrm{Na}_{2} \mathrm{O}$ loss, relative to $\mathrm{TiO}_{2}$, in loess-derived soils in Illinois are very similar to those for modern $(\sim 25 \%)$ and last interglacial $(\sim 50 \%)$ soils in loess near Wanganui, New Zealand, where mean precipitation is $800-900 \mathrm{~mm} \mathrm{yr}^{-1}$ (Graham et al., 2001). These comparisons indicate to us that loess-derived modern soils and paleosols in central Alaska have experienced at least as much $\mathrm{Na}_{2} \mathrm{O}$ loss as those in semiarid to subhumid parts of China and almost as much $\mathrm{Na}_{2} \mathrm{O}$ loss as modern loess-derived soils in the humid climates of Illinois and New Zealand. In Illinois and New Zealand, last-interglacial paleosols have experienced about twice as much $\mathrm{Na}_{2} \mathrm{O}$ loss as those in Alaska. However, at least in Illinois, the last interglacial paleosol complex may have developed over a period as long as $\sim 50,000 \mathrm{yr}$ (Grimley et al., 2003).

\section{CHEMICAL WEATHERING OF CLAY MINERALS}

Weathering of silicates is also reflected in the clay mineral suites of central Alaskan soils and paleosols. The sources of loess, sediments of the Tanana and Yukon Rivers, have abundant amounts of clay-sized smectite. X-ray diffraction patterns of glycolated river clays show sharp smectite peaks, suggesting that these clays are well-crystallized. However, modern soils and most buried soils are characterized by an absence of smectite, or the presence of only broad smectite peaks with low-angle plateaus. These observations indicate that whatever smectite may have been present in the loesses initially has been depleted or at least altered significantly by weathering and pedogenesis. Chlorite and mica also appear to have experienced some depletion in some modern soils and paleosols.

Birkeland (1999) summarized the geography of soil clay mineralogy and showed there is a strong relation of clay minerals to climate. Smectite is most common in soils of the plains, plateaus, and deserts of the central and western U.S.A., where Entisols, Aridisols, Mollisols, or Vertisols are found. In these semiarid or arid climates, grassland or desert shrubs dominate and alkaline conditions prevail, even in soils on well-drained landscape positions. In other climates, where conditions are humid and welldrained soils form under acidic, forest vegetation, smectite is absent and other clay minerals predominate. Examples include kaolinite in Ultisols of the southeastern U.S.A. or vermiculite in Spodosols of the northeastern U.S.A. The absence or minimal amounts of smectite in central Alaskan soils and paleosols suggests that conditions of pedogenesis at present and in the past were not conducive to the preservation of well-crystallized smectite, despite its abundance in the source sediments. This indicates that at present and in most periods of the past, conditions were likely humid and acidic enough that smectite, probably originally present in the loess, may have been largely depleted.

\section{CHEMICAL WEATHERING OF CARBONATE MINERALS}

Central Alaskan soils, paleosols, and loesses, even those that appear unaltered in the field, have probably lost much of their original carbonate. This interpretation is based on low $\mathrm{CaCO}_{3}$, $\mathrm{CaO} / \mathrm{TiO}_{2}$, and $\mathrm{MgO} / \mathrm{TiO}_{2}$ in almost all of the loesses and paleosols, combined with the observation that the main source sediments (silts of the Tanana and Yukon Rivers) are calcareous. In contrast, what appear to be unaltered loesses in mid-latitude regions such as China (Gallet et al., 1996; Jahn et al., 2001) and Illinois (Muhs et al., 2001b; Grimley et al., 2003) have $\mathrm{CaCO}_{3}$ contents or $\mathrm{CaO} / \mathrm{TiO}_{2}$ that indicate little or no leaching of carbonates below the zones of pedogenesis, at least for loess of last-glacial age. Rare occurrences of low-carbonate zones in lastglacial loess in Kansas, Iowa, and Illinois are interpreted to be the result of syndepositional leaching under relatively low sedimentation rates (Swineford and Frye, 1951; Kleiss, 1973; Muhs and Bettis, 2000). Higher-carbonate zones within the same midcontinent sections studied by these latter workers are interpreted to be zones of more rapid sedimentation rate.

Lack of carbonates within many zones of central Alaskan sections, including those parts that appear to be unaltered loess, suggests that vegetation at the time of loess sedimentation was acidic enough that carbonates were leached syndepositionally. 


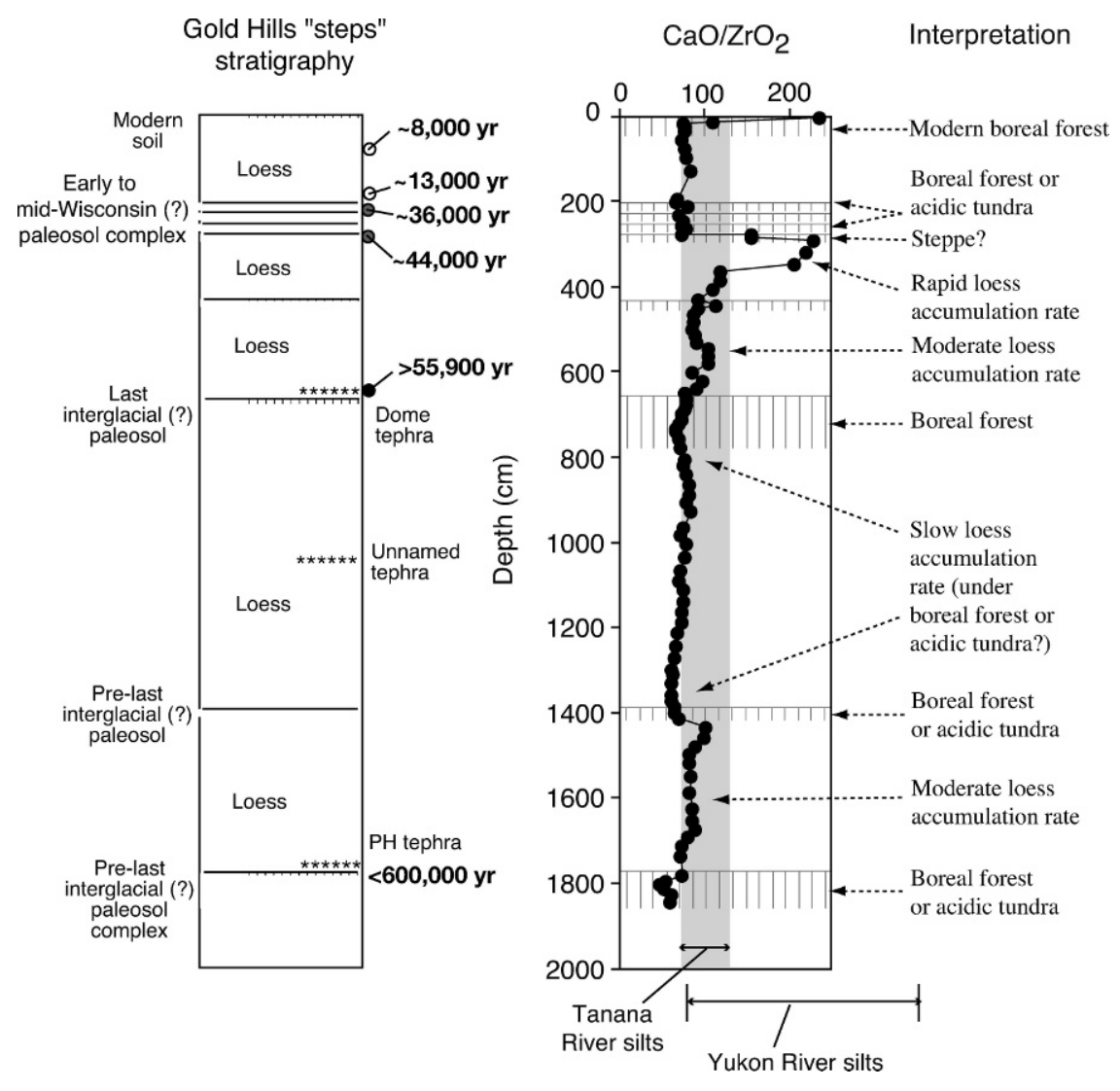

FIGURE 13. Plot of $\mathrm{CaO} / \mathrm{ZrO}_{2}$
for the Gold Hill loess section
(taken from Fig. 8) and the ranges
of $\mathrm{CaO} / \mathrm{ZrO}$ for the loess source
sediments (silt fractions of the
Tanana River and Yukon River).
Also shown are inferred vegetation
types during periods of soil forma-
tion and inferred rates of sedimen-
tation during periods of loess
accumulation.

This implies that acid-producing vegetation (boreal forest or acidic tundra) was present during both the times of loess deposition and subsequent periods of soil formation. In midcontinental North America, loess of last-glacial age, such as that in Iowa and Illinois, is highly calcareous below the zone of modern soil formation (Muhs and Bettis, 2000; Muhs et al., 2001b). Nevertheless, based on macrofossils, pollen, and faunas, vegetation in most of the midcontinent at the time of full-glacial loess sedimentation was likely boreal forest, tundra, or a mosaic of boreal forest and tundra (Baker et al., 1986; Schwert et al., 1997; Curry and Baker, 2000). Despite the presence of this acidic vegetation, carbonates were preserved in midcontinent loess. However, last glacial loess accumulation rates in that region were among the highest in the world (Bettis et al., 2003), such that sedimentation kept ahead of syndepositional leaching. Thus, another implication of the Alaskan results is that loess sedimentation rates in many periods of the past were probably relatively slow.

\section{IMPLICATIONS OF CHEMICAL WEATHERING FOR PAST ENVIRONMENTS}

It is possible to infer something about past vegetation as well as loess sedimentation rates in central Alaska using the trends of chemical weathering vs. depth, coupled with a comparison of river source sediments. Here we present a summary of possible paleoenvironmental conditions using Gold Hill as an example (Fig. 13). The hypothesized pre-last-interglacial paleosols at $\sim 1800 \mathrm{~cm}$ depth and $\sim 1400 \mathrm{~cm}$ depth have lower $\mathrm{CaO} / \mathrm{ZrO}_{2}$ values than either Tanana or Yukon River silts. From this we infer that both paleosols formed under boreal forest or acidic tundra vegetation. This inference is supported by evidence of considerable $\mathrm{Na}_{2} \mathrm{O}$ and $\mathrm{SiO}_{2}$ loss in both paleosols. The loess between these two paleosols has higher $\mathrm{CaO} / \mathrm{ZrO}_{2}$ values that fall within the lower ranges of the river silts. This trend suggests a moderate rate of loess accumulation, rapid enough that soils did not form, but slow enough that not all carbonates were preserved. In contrast, the loess between $\sim 1400$ and $\sim 800 \mathrm{~cm}$ shows lower $\mathrm{CaO} / \mathrm{ZrO}_{2}$ values, almost all of which are lower than the silts from either source river. We interpret this depth trend to indicate a relatively low rate of loess sedimentation with syndepositional leaching under acidic tundra or boreal forest. Farther up-section at Gold Hill, what we infer to be a last-interglacial paleosol complex, between $\sim 770$ and $\sim 670 \mathrm{~cm}$, shows considerable $\mathrm{CaO}$ depletion. The last interglacial paleosol at Eva Creek shows the same trends. Plant macrofossil and pollen data indicate that this soil formed under a Picea and Betula-dominated boreal forest (Péwé et al., 1997; Muhs et al., 2001a). Above the hypothesized last interglacial paleosol complex at Gold Hill, loess between $\sim 670$ and $\sim 450 \mathrm{~cm}$ shows $\mathrm{CaO} / \mathrm{ZrO}_{2}$ within the range of river source sediments, suggesting moderate loess accumulation rates. Loess between $\sim 450$ and $\sim 300 \mathrm{~cm}$, however, shows much higher $\mathrm{CaO} / \mathrm{ZrO}_{2}$. The uppermost part of this loess has $\mathrm{CaO} / \mathrm{ZrO}_{2}$ values that exceed those of Tanana River silts (though still within the range of Yukon River silts), from which we infer relatively rapid loess deposition. The paleosol that caps this loess at $\sim 290-280 \mathrm{~cm}$ also has high $\mathrm{CaO} / \mathrm{ZrO}_{2}$ and calcite. This composition implies non-acidic vegetation, such as grass or steppe. The calibrated radiocarbon age of $\sim 44,000 \mathrm{cal} \mathrm{yr}$ B.P. for humic acids from this paleosol indicates that this drier period could have occurred during the mid-Wisconsin, but we stress that this age could be a minimum estimate. Our cautionary note stems from the observation that a similar, carbonate-rich zone occurs at Halfway House, but with a radiocarbon age that is $>50,000 \mathrm{yr}$ B.P. Above the calcareous paleosol, three younger paleosols in a complex from $\sim 280$ to $\sim 210 \mathrm{~cm}$ all show low $\mathrm{CaO} /$ $\mathrm{ZrO}_{2}$ values, implying acidic tundra or boreal forest vegetation. If this paleosol complex dates to the mid-Wisconsin interstadial period, an inference of acidic tundra or boreal forest vegetation is consistent with pollen records for this period reported by 
Anderson and Lozhkin (2001). Loess above this paleosol complex, between $\sim 210$ and $\sim 50 \mathrm{~cm}$, shows $\mathrm{CaO} / \mathrm{ZrO}_{2}$ values within the lower part of the range of the river source sediments, implying some syndepositional leaching with a relatively low rate of loess accumulation. ${ }^{10} \mathrm{Be}$ accumulation rate ages suggest that this loess could have been deposited during the Holocene or the late glacial period. Higher values of $\mathrm{CaO} / \mathrm{ZrO}_{2}$ also are found in the uppermost loess unit at Eva Creek, between depths of $\sim 180$ and $\sim 400 \mathrm{~cm}$, where we have a radiocarbon age of $\sim 25,000 \mathrm{cal}$ yr B.P. (Fig. 8). Thus, it is possible that the early part of the last glacial period, with a more rapid loess accumulation rate, is missing at Gold Hill. Overall, the loess-paleosol stratigraphic record indicates variable rates of loess sedimentation, punctuated by periods of soil formation. However, with the exception of an early-to-midWisconsin period, both loess and paleosol zones suggest acidic vegetation, either tundra or boreal forest.

\section{IMPLICATIONS OF LOESS-PALEOSOL WEATHERING FOR PLEISTOCENE MAMMALS IN CENTRAL ALASKA}

A recurring paleoenvironmental hypothesis in Alaska and Yukon Territory is derived from the fossil vertebrate record of the Quaternary, which includes a number of large mammal grazers, such as mammoth (Mammuthus), horse (Equus), and bison (Bison). Based on radiocarbon ages in Guthrie (1990, 2006), mammoth, horse, and bison would have been present in interior Alaska during the last (late Wisconsin) glacial period, midWisconsin interstadials, and possibly earlier. In a series of papers, Guthrie $(1990,2001,2006)$ argued that the presence of these large grazing mammals in the fossil record requires that Alaska and at least parts of Yukon Territory must have had a grassland vegetation at various times in its past. This "Mammoth Steppe" biome is hypothesized to have existed because neither boreal forest nor tundra species now dominant in Alaska and Yukon Territory would have provided enough nutritional value for large grazers (Guthrie, 2001). Furthermore, Guthrie (1990, 2001), Laxton et al. (1996), Schweger (1997), Walker et al. (2001), Goetcheus and Birks (2001), and Zazula et al. (2006) stressed that grasses of the hypothesized Mammoth Steppe could have been supported by periodic deposition of high-nutrient-status loess deposits.

Chemical data presented here suggest that in many parts of the loess sections around Fairbanks, vegetation was acidic during periods of both loess sedimentation and soil formation. Indeed, at the Gold Hill section, only one period, dating to the earlyWisconsin or mid-Wisconsin, shows any significant evidence of carbonate retention during loess fall and subsequent soil formation. Acidic tundra or boreal forest vegetation is implied for all other periods of loess fall or soil formation.

At least two explanations can reconcile the central Alaskan loess record with the presence of large grazing mammals in an arid, steppe vegetation of the last glacial period (Guthrie, 1990, 2001, 2006). One is that the loess record around Fairbanks is not representative of paleoenvironmental conditions in the rest of interior Alaska. Study of other loess sections in interior Alaska can test this hypothesis, of course. Nevertheless, the explanation is still not very satisfactory considering that many of the large, grazing mammal fossils themselves have been found in or near Fairbanks (Guthrie, 1990). The other explanation is that central Alaskan loess sections simply have not preserved the last glacial period in their records. Muhs et al. (2003a) reported that existing radiocarbon, ${ }^{10} \mathrm{Be}$, and thermoluminescence ages do not permit an interpretation of much, if any, loess accumulation in central Alaska during the last glacial period. Our only dated records of possible last-glacial loess are from the upper parts of the sections at Halfway House, Gold Hill, and Eva Creek, but even in these sections, a complete last-glacial loess record is at best uncertain.

Vegetation itself may explain the lack of loess records dating to the last glacial period in central Alaska. Tsoar and Pye (1987) and Begét (1988) pointed out that steppe or herb tundra vegetation communities have very low roughness compared to boreal forest or even shrub tundra. As a consequence, although there were expanded glaciers in Alaskan mountain ranges during the last glacial period (Péwé, 1975), and presumably greater silt production, low-roughness vegetation may have allowed little accumulation and preservation of loess on most central Alaskan landscapes except where favorable conditions allowed it. Elsewhere in Alaska, where lakes record loess deposition (and hence vegetation plays little or no role in accumulation), full-glacial loess sedimentation is well documented (Muhs et al., 2003b). Fullglacial loesses and paleosols, with good stratigraphic and chronological control, also have been reported from western Yukon Territory, but primarily in valley-bottom settings (Froese et al., 2002; Sanborn et al., 2006). Interestingly, geochemical data from last-glacial-age Yukon Territory loess and paleosol sequences indicate little or no chemical weathering. Sanborn et al. (2006) interpreted the soil-forming environment to have been a base-rich one under steppe or tundra. It is possible that similar conditions existed in central Alaska, but that the stratigraphic records in the sections we studied simply have not preserved them.

\section{Conclusions}

Modern soils and paleosols in central Alaskan loess show significant loss of $\mathrm{Na}_{2} \mathrm{O}$ and $\mathrm{SiO}_{2}$, probably due to depletion of Na-plagioclase. Plagioclase losses in Alaskan soils and paleosols are comparable to those in some semiarid, subhumid, and humid soils and paleosols in loess of midlatitude regions, such as China and midcontinental North America. Smectite, present in the river sediments that are the sources of loess, is absent or poorly preserved in modern soils and paleosols. With few exceptions, carbonates are also absent in most Alaskan paleosols, despite the fact that sediments of the source rivers are calcareous. An unexpected result of our studies is that carbonates are depleted not only in the modern soils and most paleosols, but also, with a couple exceptions, in most of what appears to be "unaltered" loess. This observation suggests syndepositional carbonate leaching, the result of slow loess sedimentation under what was probably an acidic vegetation.

Thus, despite the short, cool summers, low precipitation, and low rates of organic matter decomposition, high-latitude soils of Alaska experience significant chemical weathering and have experienced it in past interglacial and interstadial periods. The loss of plagioclase, smectite, and carbonates in many Alaskan paleosols, comparable to that in modern Alaskan soils, indicates that conditions during past interglacials and interstadials were at least as warm and precipitation was at least as great as present. We interpret many of the soil-forming periods of the past to have been dominated by either acidic tundra or boreal forest.

\section{Acknowledgments}

This study was supported by the Earth Surface Dynamics Program of the U.S. Geological Survey, and is a contribution to the "Eolian history of North America" and LITE ("Last 
Interglacial: Timing and Environment") Projects. Art Bettis helped us collect charcoal at the Halfway House locality, and Tom Stafford provided the radiocarbon ages from Eva Creek. We thank Paul Carrara and Walt Dean, both of the U.S. Geological Survey, Art Bettis (University of Iowa), and an anonymous reviewer for helpful comments on an earlier version of the manuscript.

\section{References Cited}

Abbott, M. B., and Stafford, T. W., Jr., 1996: Radiocarbon geochemistry of modern and ancient Arctic lake systems, Baffin Island, Canada. Quaternary Research, 45: 300-311.

Ager, T. A., and Brubaker, L., 1985: Quaternary palynology and vegetational history of Alaska. In Bryant, V. M., Jr., and Holloway, R. G. (eds.), Pollen Records of LateQuaternary North American Sediments. Dallas, Texas: American Association of Stratigraphic Palynologists Foundation, 353-383.

Anderson, P. M., and Brubaker, L. B., 1994: Vegetation history of northcentral Alaska: A mapped summary of late-Quaternary pollen data. Quaternary Science Reviews, 13: 71-92.

Anderson, P. M., and Lozhkin, A. V., 2001: The Stage 3 interstadial complex (Karginskii/middle Wisconsinan interval) of Beringia: variations in paleoenvironments and implications for paleoclimatic interpretations. Quaternary Science Reviews, 20: 93-125.

Anderson, S. P., 2007: Biogeochemistry of glacial landscape systems. Annual Review of Earth and Planetary Sciences, 35: 375-399.

Baker, R. G., Rhodes, R. S., II, Schwert, D. P., Ashworth, A. C., Frest, T. J., Hallberg, G. R., and Janssens, J. A., 1986: A fullglacial biota from southeastern Iowa, USA. Journal of Quaternary Science, 1: 91-107.

Begét, J. E., 1988: Tephras and sedimentology of frozen loess. In Senneset, K. (ed.), Fifth International Permafrost Conference Proceedings, Volume 1. Trondheim: Tapir, 672-677.

Begét, J. E., 1990: Middle Wisconsin climate fluctuations recorded in central Alaskan loess. Géographie Physique et Quaternaire, 44: $3-13$

Begét, J. E., 1996: Tephrochronology and paleoclimatology of the last interglacial-glacial cycle recorded in Alaskan loess deposits. Quaternary International, 34-36: 121-126.

Begét, J. E., 2001: Continuous Late Quaternary proxy climate records from loess in Beringia. Quaternary Science Reviews, 20: 499-507.

Begét, J. E., Stone, D. B., and Hawkins, D. B., 1990: Paleoclimatic forcing of magnetic susceptibility variations in Alaskan loess during the late Quaternary. Geology, 18: 40-43.

Berger, G. W., 2003: Luminescence chronology of late Pleistocene loess-paleosol and tephra sequences near Fairbanks, Alaska. Quaternary Research, 60: 70-83.

Berger, G. W., and Péwé, T. L., 2001: Last interglacial age of the Eva Forest Bed, central Alaska, from thermoluminescence dating of bracketing loess. Quaternary Science Reviews, 20: 485-498.

Berger, G. W., Péwé, T. L., Westgate, J. A., and Preece, S. J., 1996: Age of Sheep Creek tephra (Pleistocene) in central Alaska from thermoluminescence dating of bracketing loess. Quaternary Research, 45: 263-270.

Bettis, E. A., III, Muhs, D. R., Roberts, H. M., and Wintle, A. G., 2003: Last glacial loess in the conterminous U.S.A. Quaternary Science Reviews, 22: 1907-1946.

Bigelow, N. H., and Edwards, M. E., 2001: A 14,000 yr paleoenvironmental record from Windmill Lake, central Alaska: late glacial and Holocene vegetation in the Alaska Range. Quaternary Science Reviews, 20: 203-215.

Birkeland, P. W., 1999: Soils and geomorphology. New York: Oxford University Press, $430 \mathrm{pp}$.
Budahn, J. R., and Wandless, G. A., 2002: Instrumental neutron activation by long count. U.S. Geological Survey Open-File Report, OF 02-0223: X1-X13.

Curry, B. B., and Baker, R. G., 2000: Palaeohydrology, vegetation, and climate since the late Illinois Episode $(\sim 130 \mathrm{ka})$ in south-central Illinois. Palaeogeography, Palaeoclimatology, Palaeoecology, 155: 59-81.

Eberl, D. D., 2004: Quantitative mineralogy of the Yukon River system: changes with reach and season, and determining sediment provenance. American Mineralogist, 89: 1784-1794.

Edwards, M. E., and Armbruster, W. S., 1989: A tundra-steppe transition on Kathul Mountain, Alaska, U.S.A. Arctic and Alpine Research, 21: 296-304.

Edwards, M. E., and 18 others., 2000: Pollen-based biomes for Beringia 18,000, 6000 and $0{ }^{14} \mathrm{C}$ yr BP. Journal of Biogeography, 27: 521-554.

Edwards, M. E., Hamilton, T. D., Elias, S. A., Bigelow, N. H., and Krumhardt, A. P., 2003: Interglacial expansion of boreal forest limit in the Noatak Valley, northwest Alaska: evidence from an exhumed river-cut bluff and debris apron. Arctic, Antarctic, and Alpine Research, 35: 460-468.

Fairbanks, R. G., Mortlock, R. A., Chiu, T.-C., Cao, L., Kaplan, A., Guilderson, T. P., Fairbanks, T. W., Bloom, A L., Grootes, P. M., and Nadeau, M.-J., 2005: Radiocarbon calibration curve spanning 0 to 50,000 years B.P. based on paired ${ }^{230} \mathrm{Th} /{ }^{234} \mathrm{U} /{ }^{238} \mathrm{U}$ and ${ }^{14} \mathrm{C}$ dates on pristine corals. Quaternary Science Reviews, 24: 1781-1796.

Froese, D., Westgate, J., Preece, S., and Storer, J., 2002: Age and significance of the Late Pleistocene Dawson tephra in eastern Beringia. Quaternary Science Reviews, 21: 2137-2142.

Gallet, S., Jahn, B., and Torii, M., 1996: Geochemical characterization of the Luochuan loess-paleosol sequence, China, and paleoclimatic implications. Chemical Geology, 133: 67-88.

Goetcheus, V. G., and Birks, H. H., 2001: Full-glacial upland tundra vegetation preserved under tephra in the Beringia National Park, Seward Peninsula, Alaska. Quaternary Science Reviews, 20: 135-147.

Graham, I. J., Ditchburn, R. G., and Whitehead, N. E., 2001: Be isotope analysis of a $0-500 \mathrm{ka}$ loess-paleosol sequence from Rangitatau East, New Zealand. Quaternary International, 76/77: $29-42$.

Grimley, D. A., Follmer, L. R., Hughes, R. E., and Solheid, P. A., 2003: Modern, Sangamon and Yarmouth soil development in loess of unglaciated southwestern Illinois. Quaternary Science Reviews, 22: 225-244.

Guthrie, R. D., 1990: Frozen fauna of the mammoth steppe: the story of Blue Babe. Chicago: University of Chicago Press, $323 \mathrm{pp}$.

Guthrie, R. D., 2001: Origin and causes of the mammoth steppe: a story of cloud cover, woolly mammal tooth pits, buckles, and inside-out Beringia. Quaternary Science Reviews, 20: 549-574.

Guthrie, R. D., 2006: New carbon dates link climatic change with human colonization and Pleistocene extinctions. Nature, 441: 207-209.

Harrison, S. P., Kutzbach, J. E., Prentice, I. C., Behling, P. J., and Sykes, M. T., 1995: The response of northern hemisphere extratropical climate and vegetation to orbitally induced changes in insolation during the last interglaciation. Quaternary Research, 43: 174-184.

Höfle, C., and Ping, C.-L., 1996: Properties and soil development of late-Pleistocene paleosols from Seward Peninsula, northwest Alaska. Geoderma, 71: 219-243.

Hopkins, D. M., 1963: Geology of the Imuruk Lake area, Seward Peninsula, Alaska. U.S. Geological Survey Bulletin, 1141-C, $101 \mathrm{pp}$.

Jahn, B., Gallet, S., and Han, J., 2001: Geochemistry of the Xining, Xifeng and Jixian sections, Loess Plateau of China: eolian dust provenance and paleosol evolution during the last 140 ka. Chemical Geology, 178: 71-94. 
Kleiss, H. J., 1973: Loess distribution along the Illinois soildevelopment sequence. Soil Science, 115: 194-198.

Lagroix, F., and Banerjee, S. K., 2002: Paleowind directions from the magnetic fabric of loess profiles in central Alaska. Earth and Planetary Science Letters, 195: 99-112.

Laxton, N. F., Burn, C. R., and Smith, C. A. S., 1996: Productivity of loessal grasslands in the Kluane Lake region, Yukon Territory and the Beringian "production paradox." Arctic, 49: 129-140.

Liu, X. M., Hesse, P., Rolph, T., and Begét, J. E., 1999: Properties of magnetic mineralogy of Alaskan loess: evidence for pedogenesis. Quaternary International, 62: 93-102.

McGeehin, J., Burr, G. S., Jull, A. J. T., Reines, D., Gosse, J., Davis, P. T., Muhs, D., and Southon, J. R., 2001: Steppedcombustion ${ }^{14} \mathrm{C}$ dating of sediment: a comparison with established techniques. Radiocarbon, 43: 255-261.

Moore, D. M., and Reynolds, R. C., Jr., 1989: X-ray diffraction and the identification and analysis of clay minerals. Oxford: Oxford University Press, 332 pp.

Muhs, D. R., and Bettis, E. A., III, 2000: Geochemical variations in Peoria Loess of western Iowa indicate paleowinds of midcontinental North America during last glaciation. Quaternary Research, 53: 49-61.

Muhs, D. R., and Bettis, E. A., III, 2003: Quaternary loesspaleosol sequences as examples of climate-driven sedimentary extremes. Geological Society of America Special Paper, 370: 53-74.

Muhs, D. R., and Budahn, J. R., 2006: Geochemical evidence for the origin of late Quaternary loess in central Alaska. Canadian Journal of Earth Sciences, 43: 323-337.

Muhs, D. R., Ager, T. A., and Begét, J., 2001a: Vegetation and paleoclimate of the last interglacial period, central Alaska. Quaternary Science Reviews, 20: 41-61.

Muhs, D. R., Bettis, E. A., III, Been, J., and McGeehin, J., 2001b: Impact of climate and parent material on chemical weathering in loess-derived soils of the Mississippi River valley. Soil Science Society of America Journal, 65: 1761-1777.

Muhs, D. R., Ager, T. A., Bettis, E. A., III, McGeehin, J., Been, J. M., Begét, J. E., Pavich, M. J., Stafford, T. W., Jr., and Stevens, D. S. P., 2003a: Stratigraphy and paleoclimatic significance of late Quaternary loess-paleosol sequences of the last interglacial-glacial cycle in central Alaska. Quaternary Science Reviews, 22: 1947-1986.

Muhs, D. R., Ager, T. A., Been, J., Bradbury, J. P., and Dean, W. E., 2003b: A late Quaternary record of eolian silt deposition in a maar lake, St. Michael Island, western Alaska. Quaternary Research, 60: 110-122.

Péwé, T. L., 1975: Quaternary geology of Alaska. U.S. Geological Survey Professional Paper, 835, 145 pp.

Péwé, T. L., Wahrhaftig, C., and Weber, F. R., 1966: Geologic map of the Fairbanks quadrangle, Alaska. U.S. Geological Survey Miscellaneous Investigations Map, I-455, scale: 1:250,000.

Péwé, T. L., Berger, G. W., Westgate, J. A., Brown, P. M., and Leavitt, S. W., 1997: Eva Interglaciation Forest Bed, unglaciated east-central Alaska: global warming 125,000 years ago. Geological Society of America Special Paper, 319: 1-54.
Preece, S. J., Westgate, J. A., Stemper, B. A., and Péwé, T. L., 1999: Tephrochronology of late Cenozoic loess at Fairbanks, central Alaska: Geological Society of America Bulletin, 111: 71-90.

Rieger, S., Schoephorster, D. B., and Furbush, C. E., 1979: Exploratory soil survey of Alaska. Washington, D.C.: U.S. Department of Agriculture, Soil Conservation Service, U.S. Government Printing Office, 213 pp.

Sanborn, P. T., Smith, C. A. S., Froese, D. G., Zazula, G. D., and Westgate, J. A., 2006: Full-glacial paleosols in perennially frozen loess sequences, Klondike goldfields, Yukon Territory, Canada. Quaternary Research, 66: 147-157.

Schweger, C. E., 1997: Late Quaternary palaeoecology of the Yukon: a review. In Danks, H. V., and Downes, J. A. (eds.), Insects of the Yukon. Ottawa: Biological Survey of Canada Monograph Series, 59-72.

Schwert, D. P., Torpen-Kreft, H. J., and Hajic, E. R., 1997: Characterization of the Late-Wisconsinan tundra/forest transition in midcontinental North America using assemblages of beetle fossils. Quaternary Proceedings, 5: 237-243.

Swineford, A., and Frye, J. C., 1951: Petrography of the Peoria Loess in Kansas. Journal of Geology, 59: 306-322.

Tsoar, H., and Pye, K., 1987: Dust transport and the question of desert loess formation. Sedimentology, 34: 139-153.

Vetter, M. A., 2000: Grasslands of the Aishihik-Sekulmun Lakes area, Yukon Territory, Canada. Arctic, 53: 165-173.

Vlag, P. A., Oches, E. A., Banerjee, S. K., and Solheid, P. A., 1999: The paleoenvironmental-magnetic record of the Gold Hill steps loess section in central Alaska. Physics and Chemistry of the Earth (A), 24: 779-783.

Walker, D. A., and Everett, K. R., 1991: Loess ecosystems of northern Alaska: regional gradient and toposequence at Prudhoe Bay. Ecological Monographs, 61: 437-464.

Walker, D. A., Bockheim, J. G., Chapin, F. S., III, Eugster, W., Nelson, F. E., and Ping, C. L., 2001: Calcium-rich tundra, wildlife, and the "Mammoth Steppe." Quaternary Science Reviews, 20: 149-163.

Westgate, J. A., Stemper, B. A., and Péwé, T. L., 1990: A 3 m.y. record of Pliocene-Pleistocene loess in interior Alaska. Geology, 18: 858-861.

Zazula, G. D., Froese, D. G., Westgate, J. A., La Farge, C., and Mathewes, R. W., 2005: Paleoecology of Beringian "packrat" middens from central Yukon Territory, Canada. Quaternary Research, 63: 189-198.

Zazula, G. D., Schweger, C. E., Beaudoin, A. B., and McCourt, G. H., 2006: Macrofossil and pollen evidence for full-glacial steppe within an ecological mosaic along the Bluefish River, eastern Beringia. Quaternary International, 142-143: 2-19.

Zazula, G. D., Froese, D. G., Elias, S. A., Kuzmina, S., and Mathewes, R. W., 2007: Arctic ground squirrels of the mammoth-steppe: paleoecology of late Pleistocene middens $\left(\sim 24000-29450{ }^{14} \mathrm{C}\right.$ yr BP), Yukon Territory, Canada. Quaternary Science Reviews, 26: 979-1003. 